RESEARCH ARTICLE

\title{
The Visual Effects Associated with Head-Mounted Displays
}

\author{
Jing Yuan ${ }^{1,2}$, Behzad Mansouri ${ }^{3}$, Jeff H Pettey ${ }^{4}$, Sarah Farukhi Ahmed ${ }^{5}$ and S Khizer Khaderi, ${ }^{1,4^{*}}$ \\ ${ }^{1}$ Eye Center, UC Davis Health System, USA \\ ${ }^{2}$ Eye Center, Renmin Hospital of Wuhan University, China \\ ${ }^{3}$ Section of Neurology, Department of Internal Medicine, Ophthalmology, Biomedical Engineering Program, \\ Electrical \& Computer Engineering, University of Manitoba, Winnipeg, Canada \\ ${ }^{4}$ Moran Eye Center, University of Utah School of Medicine, USA \\ ${ }^{5}$ Gavin Herbert Eye Center, University of California, USA
}

*Corresponding author: S. Khizer Khaderi, Moran Eye Center, University of Utah School of Medicine, Salt Lake City, UT 84132, USA, E-mail:khizer@vizzario.com

\begin{abstract}
Objectives: To investigate Visually-Induced Motion Sickness (VIMS) and visual effects associated with the Head-Mounted Displays (HMDs) most commonly used in Virtual Reality (VR) systems.

Methods: A comprehensive search query was performed on the Medline/PubMed, EMBASE, CENTRAL, ACM Digital Library, and IEEE Xplore databases. We identified population-based studies that evaluated HMDs as an independent factor for visual discomfort. Potential variables relevant to HMD discomfort, including system features (e.g. optical characteristics), subject characteristics (e.g. gender), and task characteristics (e.g. duration, vection, and task content) were reviewed. Total severity scores of Simulator Sickness Questionnaires (SSQT), oculomotor scores of Simulator Sickness Questionnaires (SSQO), and Visual Strain Questionnaires scores (VSQ) were used to measure HMD discomfort impact.
\end{abstract}

Results: We analyzed data for 1040 participants from a total of seventeen studies, all published between 1998 and 2015. Our review demonstrated that exposure to HMDs resulted in higher SSQT and SSQO mean change scores, compared with exposure to traditional displays such as TV and desktop computer displays. Furthermore, HMD exposure duration had a significant impact on the mean change scores of SSQT, SSQO, and VSQ. Our analysis also showed that HMD discomfort was affected by all three of the variables we evaluated.

Conclusion: This meta-analysis qualifies the risk factors causing discomfort after exposure to HMDs. We recommend that HMD manufacturers increase their awareness of, and address, these visual discomfort issues in their products.

\section{Keywords}

Head-mounted display, Virtual reality, Virtual environment, Visual discomfort

\begin{abstract}
Abbreviations
HMD: Head-Mounted Display; NED: Near-to-Eye Display; VE: Virtual Environment; VR: Virtual Reality; 2D: Two-Dimensional; S3D: Stereoscopic Three-Dimensional; IPD: Inter-Pupillary Distance; FOV: Field of View; VIMS: Visually-Induced Motion Sickness; D: Disorientation; O: Oculomotor disturbance; N: Nausea; SSQ: Simulator Sickness Questionnaire; VSQ: Visual Strain Questionnaire; DK2: Developmental Kit 2; CI: Confidence Interval; SS: Simulator Sickness
\end{abstract}

\section{Introduction}

In recent years, Virtual Reality (VR) has become more commonplace, with rapid adoption into daily life. VR is a non-invasive simulation technology that provides an immersive, realistic, three-dimensional (3D) computer-simulated environment in which people perform tasks and experience activities as if they were in the real world. The most direct experience of VR is provided by fully immersive VR systems. The most widely adopted VR systems display is a simulated environment through special wearable head-mounted visual displays (HMDs). HMDs have evolved over the past five years from tethered systems comprising of screens and lenses fitted into a helmet, to relatively inexpensive systems that utilize mobile smart devices and fit

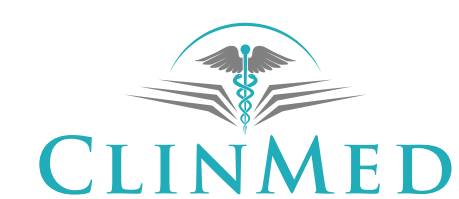

INTERNATIONAL LIBRARY
Citation: Yuan J, Mansouri B, Pettey JH, Ahmed SF, Khaderi SK (2018) The Visual Effects Associated with Head-Mounted Displays. Int J Ophthalmol Clin Res 5:085. doi.org/10.23937/2378-346X/1410085 Received: April 14, 2017: Accepted: April 16, 2018: Published: April 18, 2018

Copyright: (C) 2018 Yuan J, et al. This is an open-access article distributed under the terms of the Creative Commons Attribution License, which permits unrestricted use, distribution, and reproduction in any medium, provided the original author and source are credited. 
into a light weight lens system. The optics within the HMDs vary from monocular (one eye view), binocular (both eyes view screen) and dichoptic (both eyes view different screen/image or image can be stereoscopic, adding depth cues). Recent advancements in hardware have included eye tracking and the use of multifocal optics.

Although HMDs have recently been introduced to the general public, they are not a new phenomenon (Table 1). As early as the 1960s, computer graphics pioneer Ivan Sutherland developed the first HMD, which made it possible to overlay virtual images on the real world $[1,2]$. HMD technology gradually evolved through the 1970 s with use across military, industry, scientific research and entertainment domains. The early commercially available HMDs had limited applications due to their narrow Field-Of-View (FOV) and inherent cumbersomeness in weight, physical restrictions, and system parameters. Recent advancements have been directed toward making HMDs more comfortable for longer duration of use. Recent HMD products including Samsung Gear, HTC Vive, Oculus Rift, FOVE, and Google Daydream have become commercially available and increasingly commonplace as a result of technical advancements. For example, the latest version of the Oculus Rift at this time, the Development Kit 2 (DK2), has a higher resolution, higher refresh rate (i.e., the frequency with which a display's image is updated), lower persistence (which aids in removing motion blur) and more advanced positional tracking allowing for precise movement, when compared to its predecessor. FOVE has introduced eye tracking with real time foveal rendering to improve user experience. HMD technology advancement and cost reduction has increased its potential for widespread use.

Visually induced motion sickness (VIMS) or simulation sickness, remains an obstacle to the widespread adoption and commercial development of technologies associated with VR based HMDs $[3,4]$. With occlusive HMD systems, which by definition, is the distinguishing factor of virtual reality vs. augmented and mixed reality systems, a user is dependent on the VR system for sensory input. This dependency involves synchrony in sensory input, and the lack of this synchrony lends to visual-vestibular mismatch. The symptoms of visual-vestibular mismatch include nausea, stomach discomfort, disorientation, postural instability and visual discomfort.

It is commonly accepted that the symptoms of nausea and instability result from various sensory input conflicts, including conflicting position and movement cues, leading to a disharmonious effect on the visual and vestibular systems $[5,6]$. In addition, specific types of HMDs might have mismatch problems with the user's visual system due to improper optical design, resulting in convergence-accommodation conflict and visual discomfort or fatigue [7-13].

Table 1: Optical characteristics of representative head mounted displays in the systematically reviewed articles.

\begin{tabular}{|c|c|c|c|c|c|c|c|c|}
\hline $\begin{array}{l}\text { Representative } \\
\text { HMDs }\end{array}$ & Year & $\begin{array}{l}\text { Weight } \\
\text { (g) }\end{array}$ & $\begin{array}{l}\text { FOV }\left({ }^{\circ}\right) \text { horizontal/ } \\
\text { vertical/diagonal }\end{array}$ & $\begin{array}{l}\text { Resolution } \\
(\text { pi } \times \text { els) }\end{array}$ & $\begin{array}{l}\text { Luminance } \\
\left(\mathrm{cd} / \mathrm{m}^{2}\right)\end{array}$ & $\begin{array}{l}\text { Inter- } \\
\text { ocular } \\
\text { dist }(\mathrm{mm})\end{array}$ & $\begin{array}{l}\text { Luminance } \\
\text { difference } \\
(\%)\end{array}$ & $\begin{array}{l}\text { Vertical } \\
\text { misalignment } \\
\left({ }^{\circ}\right)\end{array}$ \\
\hline $\begin{array}{l}\text { Virtual Research } \\
\text { Flight Helmet }\end{array}$ & 1991 & 1670 & $100^{\circ}$ diagonal & $360 \times 40$ & - & - & - & - \\
\hline Virtual research V6 & 1995 & 821 & $60^{\circ}$ diagonal & $370 \times 277$ & - & $52-74$ & - & - \\
\hline Virtual research V8 & 1998 & 820 & $60^{\circ}$ diagonal & $640 \times 480$ & - & $52-74$ & - & - \\
\hline Virtual Vision Sport & c.1993 & 140 & $17.3^{\circ}$ horizontal & $160 \times 250$ & 3.9 & - & - & - \\
\hline $\begin{array}{l}\text { Sony Glasstron } \\
\text { PLM-50 }\end{array}$ & 1996 & - & $33.75^{\circ}$ diagonal & - & - & - & - & - \\
\hline Division PV100 & 1998 & - & $60^{\circ} \times 46.8^{\circ}$ & - & - & - & - & - \\
\hline ProView $^{\mathrm{TM}} \times \mathrm{L} 50$ & 1998 & - & $35^{\circ}$ diagonal & $1024 \times 768$ & - & - & - & - \\
\hline $\begin{array}{l}\text { Virtual I/O } \\
\text { i-glasses }\end{array}$ & 1995 & 226 & $30^{\circ} \times 23.6^{\circ}$ & $263 \times 230$ & 38 & 60 & - & - \\
\hline Visette 2 & 2000 & - & $105^{\circ} \times 41^{\circ}$ & - & - & - & - & - \\
\hline EyeTrek FMD-700 & 2000 & 105 & $28.5 \times 21.1 \times 35.5$ & $800 \times 600$ & - & - & - & - \\
\hline $\begin{array}{l}\text { Emagin Z800 } \\
\text { 3DVisor }\end{array}$ & 2005 & 226.8 & $40^{\circ}$ diagonal & $800 \times 600$ & - & - & - & - \\
\hline EMG iTheater BP4L & 2005 & 78 & $23.2^{\circ} \times 17.4^{\circ} \times 29.0^{\circ}$ & $320 \times 240$ & 136 & 63 & 22 & 0.5 \\
\hline $\begin{array}{l}\text { MicroOptical MyVu } \\
\text { MA-0341 }\end{array}$ & 2006 & 70 & $12^{\circ} \times 8.8^{\circ} \times 14.9^{\circ}$ & $320 \times 240$ & 97 & 62 & 5 & 0 \\
\hline Vuzi × iWear AV920 & 2008 & 82 & $22.7^{\circ} \times 17.6^{\circ} \times 28.7^{\circ}$ & $640 \times 480$ & 24 & 63 & 3 & 0.8 \\
\hline $\begin{array}{l}\text { Zeiss Cinemizer } \\
1488-603\end{array}$ & 2008 & 115 & $20.8^{\circ} \times 15.4^{\circ} \times 25.9^{\circ}$ & $640 \times 480$ & 72 & 62 & 14 & 0.1 \\
\hline $\begin{array}{l}\text { NVIS nVisor } \mathrm{S} \times \\
111\end{array}$ & 2010 & 1300 & $102^{\circ} \times 64^{\circ}$ & $1280 \times 1024$ & - & $55-73$ & - & - \\
\hline Google Glass & 2013 & 50 & $14^{\circ}$ diagonal & $640 \times 360$ & - & - & - & - \\
\hline Oculus Rift DK 1 & 2012 & 220 & $110^{\circ}$ horizontal & $640 \times 800$ & - & - & - & - \\
\hline Oculus Rift DK 2 & 2014 & 320 & $100^{\circ}$ horizontal & $960 \times 1080$ & - & - & - & - \\
\hline InViso e-case & 2000 & - & 34 diagonals & $800 \times 600$ & 109 & - & - & - \\
\hline InViso e-shades & 2000 & - & 32 diagonals & $800 \times 600$ & 78 & - & - & - \\
\hline
\end{tabular}


Early evaluation of the side effects of HMDs showed variable and inconsistent results. Notably, Peli reported no objective functional visual differences between HMDs and conventional desktop computer displays [14].

Conversely, other early studies reported high incidence of visual discomfort including eyestrain, dry eye, tearing, foreign body sensation, feeling of pressure in the eyes, aching around the eyes, headache, blurred vision, and difficulty in focusing. For example, Mon-Williams, et al. found that following a 10-minute exposure to a stereoscopic VR display, $60 \%$ of study participants reported symptoms of eyestrain, headache, and nausea [15]. This finding has been confirmed in a number of more recent studies [16-26].

Other visual problems such as myopia, heterophoria, fixation disparity, accommodation-vergence disorders, and abnormal Tear Break-Up Time (TBUT) also have been reported $[15,18,20,21,24,27,28]$. Using HMDs may cause accommodative spasm that in turn may lead to a transient myopia [20]. Continued conflict between convergence-accommodation, the user's Inter-Pupillary Distance (IPD), and/or the systems' Inter-Optical Distance (IOD) may lead to heterophoria and fixation disparity changes [15,20,29-31]. Moreover, visual symptoms are not necessarily limited to the time of ac- tual Virtual Environment (VE) immersion; rather, visual changes including visual fatigue, reduced visual acuity and heterophoria may continue after terminating exposure to HMD-based VE [25,32-34].

\section{Meta-analysis and Systematic Reviews on the Role of HMDS in Visual Discomfort}

As a result of the recent advancements in the industry of virtual technology, the growing side effects associated with it require thorough documentation and characterization. To our knowledge, there has been no review article on the role of HMDs in visual discomfort. The current existing body of literature shows mixed results and different roles for different influential variables. While some HMDs studies have found significant negative impact on visual comfort, others have not. Biocca suggested that the cause of VR-induced sickness could be a technical problem, which would disappear as the technology advanced [35]. Unfortunately, this has not been the experience so far as technological advancements have not significantly reduced visual problems [12,13,36-47] (Table 2). Therefore, the extent to which HMD design impacts visual discomfort is unclear.

We conducted a meta-analytic review of publications related to the visual effects of HMDs. By compil-

Table 2: Summary of empirical data from head mounted display meta-analysis studies.

\begin{tabular}{|c|c|c|c|c|c|c|}
\hline Author & Country & $\begin{array}{l}\text { Subjects } \\
\text { Male } \\
\text { Female }\end{array}$ & $\begin{array}{l}\text { Mean age } \\
\text { Age range } \\
\text { (years) }\end{array}$ & $H_{M D}^{a}(s)$ Used & $\begin{array}{l}\text { Time of } \\
\text { exposure }\end{array}$ & Results \\
\hline Jaeger [48] & USA & $\begin{array}{l}60 \\
42 \mathrm{M} \\
18 \mathrm{~F}\end{array}$ & $(18-40)$ & $\begin{array}{l}\text { Unidentified } \\
\text { HMD }\end{array}$ & $13-23 \min$ & $\begin{array}{l}\text { Females were significantly more affected } \\
\text { than males by simulator activities. } \\
\text { Longer time intervals were associated } \\
\text { with significantly greater symptoms } \\
\text { of SS }{ }^{b} \text { and perceived discomfort. } \\
\text { Comparison of scores between distance } \\
\text { judgment and movement production } \\
\text { activities produced no significant results. } \\
\text { Individuals who used the static simulator } \\
\text { were significantly more affected than } \\
\text { those with similar exposure times in the } \\
\text { dynamic simulator. }\end{array}$ \\
\hline Blom [45] & Spain & $\begin{array}{l}31 \\
13 \mathrm{M} \\
18 \mathrm{~F}\end{array}$ & $27.3 \pm 7.1$ & $\begin{array}{l}\text { NVIS nVisor } \\
\text { SX111 }\end{array}$ & $\begin{array}{l}\text { Two } \\
\text { exposures } \\
\text { of } 6-7 \mathrm{~min}\end{array}$ & $\begin{array}{l}\text { Limited evidence of sickness, including } \\
\text { rotated conditions. This may be due to } \\
\text { improved technologies or differences } \\
\text { in tasks, or it may be because in our } \\
\text { experiment participants had a virtual body. }\end{array}$ \\
\hline Kolasinski [49] & USA & $\begin{array}{l}40 \\
20 \mathrm{M} \\
20 \mathrm{~F}\end{array}$ & $\begin{array}{l}22.7 \pm 4.7 \\
(19-46)\end{array}$ & i-glasses ${ }^{\mathrm{TM}}$ & $20 \mathrm{~min}$ & $\begin{array}{l}\text { Sickness could be severe and may } \\
\text { involve lingering and/or delayed effects. } \\
\text { Gender differences in mean sickness } \\
\text { scores were not statistically significant. A } \\
\text { significant negative correlation between } \\
I^{\circ} D^{\complement} \text { and eyestrain symptoms and } \\
\text { between sickness scores and final level } \\
\text { reached in Ascent. }\end{array}$ \\
\hline Moss [34] & USA & $\begin{array}{l}80 \\
30 \mathrm{M} \\
50 \mathrm{~F}\end{array}$ & $\begin{array}{l}19.5 \\
(18-24)\end{array}$ & ProView $^{\mathrm{TM}}$ XL 50 & Varied & $\begin{array}{l}\text { Compared with no added delay, an } \\
\text { additional } 200 \text { ms of display delay did } \\
\text { not result in increased SS. However, } \\
\text { SS was greater when peripheral vision } \\
\text { was occluded than when it was not. } \\
\text { Peripheral vision moderated the effects } \\
\text { of image scale factor and delay on head } \\
\text { movement velocity. }\end{array}$ \\
\hline
\end{tabular}




\begin{tabular}{|c|c|c|c|c|c|c|}
\hline Ehrlich [50] & USA & $\begin{array}{l}57 \\
23 \mathrm{M} \\
34 \mathrm{~F}\end{array}$ & $\begin{array}{l}22.8 \pm 5.1 \\
(18-43)\end{array}$ & $\begin{array}{l}\text { Various } \\
\text { unidentified } \\
\text { HMDs }\end{array}$ & Not Stated & $\begin{array}{l}\text { Dropouts experienced significantly } \\
\text { more nausea than did finishers. The } \\
\text { most severe symptom for dropouts } \\
\text { was primarily disorientation followed by } \\
\text { nausea. For finishers the most severe } \\
\text { symptom was also disorientation but } \\
\text { followed equally by either nausea or } \\
\text { oculomotor discomfort. }\end{array}$ \\
\hline Stanney [32] & USA & 60 & Not Stated & $\begin{array}{l}\text { Virtual Research } \\
\text { V6 }\end{array}$ & $15-45 \min$ & $\begin{array}{l}\text { Subjective symptomatology experienced } \\
\text { by users after VE }{ }^{d} \text { exposure is } \\
\text { substantial, persistent and statistically } \\
\text { significant. }\end{array}$ \\
\hline Stanney [33] & USA & $\begin{array}{l}34 \\
20 \mathrm{M} \\
14 \mathrm{~F}\end{array}$ & $25.8 \pm 4.7$ & $\begin{array}{l}\text { Kaiser Electro } \\
\text { - Optics Virtual } \\
\text { Immersion }\end{array}$ & $30 \mathrm{~min}$ & $\begin{array}{l}\text { When post-discomfort was compared } \\
\text { to a pre-baseline, participants reported } \\
\text { more sickness afterward. Change in felt } \\
\text { limb position resulted in subjects pointing } \\
\text { higher and slightly to the left; the latter } \\
\text { difference was not statistically significant. }\end{array}$ \\
\hline Ling [43] & Netherlands & 86 & $\begin{array}{l}28.0 \pm 6.3 \\
(18-70)\end{array}$ & eMagin Z800 & $17 \mathrm{~min}$ & $\begin{array}{l}\text { No significant effect of stereoscopy on } \\
\text { simulator sickness compared with non- } \\
\text { stereoscopic viewing conditions. No } \\
\text { significant correlation between SS score } \\
\text { and level of presence. }\end{array}$ \\
\hline Lubos [46] & Germany & $\begin{array}{l}27 \\
9 \mathrm{M} \\
18 \mathrm{~F}\end{array}$ & $\begin{array}{l}21.78 \\
(19-25)\end{array}$ & Oculus Rift DK1 & $36 \mathrm{~min}$ & $\begin{array}{l}\text { Increase in simulator sickness over the } \\
\text { experiment time was significant. }\end{array}$ \\
\hline Lubos [47] & Germany & $\begin{array}{l}12 \\
9 \mathrm{M} \\
3 \mathrm{~F}\end{array}$ & $\begin{array}{l}25.33 \\
(19-36)\end{array}$ & Oculus Rift DK1 & $26 \min$ & $\begin{array}{l}\text { No significant effect of increase in } \\
\text { simulator sickness over the experiment } \\
\text { time. }\end{array}$ \\
\hline Draper [51] & USA & $\begin{array}{l}\mathrm{E} 1: 11 \\
6 \mathrm{M} \\
5 \mathrm{~F} \\
\mathrm{E} 2: 10 \\
6 \mathrm{M} \\
4 \mathrm{~F}\end{array}$ & $\begin{array}{l}E 1: 28.5 \\
(19-39) \\
E 2: 27.4(23 \\
-36)\end{array}$ & $\begin{array}{l}\text { Virtual i/O } \\
\text { i-glasses }{ }^{\mathrm{TM}}\end{array}$ & $\begin{array}{l}10,20,30 \\
\min \end{array}$ & $\begin{array}{l}\text { SS symptoms were significantly greater } \\
\text { in minification }(0.5) \text { and magnification } \\
(2.0) \text { image scale factor conditions than } \\
\text { in neutral condition (1.0). SS did not vary } \\
\text { with time delay changes. }\end{array}$ \\
\hline Pölönen [52] & Finland & $\begin{array}{l}78 \\
38 \mathrm{M} \\
40 \mathrm{~F}\end{array}$ & $\begin{array}{l}33.5 \\
(21-53)\end{array}$ & iTheater & $40 \mathrm{~min}$ & $\begin{array}{l}\text { NED use induced slight sickness, but } \\
\text { many of these shortcomings could be } \\
\text { diminished with improved NED headset } \\
\text { ergonomics and display quality. }\end{array}$ \\
\hline Pölönen [37] & Finland & $\begin{array}{l}97 \\
48 \mathrm{M} \\
49 \mathrm{~F}\end{array}$ & $\begin{array}{l}33.8 \\
(23-45)\end{array}$ & $\begin{array}{l}\text { iTheater, MyVu, } \\
\text { Vuzix, Zeiss }\end{array}$ & $40 \mathrm{~min}$ & $\begin{array}{l}\text { All NEDs induced eyestrain and sickness } \\
\text { symptoms; magnitude of these symptoms } \\
\text { varied according to the device. Adverse } \\
\text { symptoms were related to problems } \\
\text { with the display optics and design, text } \\
\text { layout, headset fit, use context, individual } \\
\text { differences. }\end{array}$ \\
\hline Merhi [53] & USA & $\begin{array}{l}24 \\
13 \mathrm{M} \\
11 \mathrm{~F}\end{array}$ & $\begin{array}{l}22 \\
(17-35)\end{array}$ & Visette - Pro & up to $50 \mathrm{~min}$ & $\begin{array}{l}\text { Commercial console video game systems } \\
\text { can induce motion sickness. }\end{array}$ \\
\hline Sharples [54] & UK & $\begin{array}{l}71 \\
38 \mathrm{M} \\
33 / \mathrm{F}\end{array}$ & Not Given & $\begin{array}{l}\text { Virtual research } \\
\text { V8 }\end{array}$ & $30 \mathrm{~min}$ & $\begin{array}{l}\text { Higher reported symptoms (nausea) in } \\
\text { HMD compared with desktop viewing } \\
\text { and in HMD compared with reality theatre } \\
\text { viewing (nausea, oculomotor symptoms, } \\
\text { disorientation). }\end{array}$ \\
\hline Takada [44] & Japan & 13 & $23 \pm 6.2$ & iWear AV920 & $2 \min$ & $\begin{array}{l}\text { 3-D movies can affect lateral body sway, } \\
\text { thereby causing VIMS }\end{array}$ \\
\hline Järvenpää [39] & Finland & $\begin{array}{l}232 \\
123 \mathrm{M} \\
109 \mathrm{~F}\end{array}$ & $\begin{array}{l}34.5 \\
(21-53)\end{array}$ & $\begin{array}{l}\text { Five unidentified } \\
\text { HMDs, likely } \\
\text { including HMDs } \\
\text { from Toni } \\
\text { Järvenpää [50] }\end{array}$ & $\begin{array}{l}40 \min , 95 \\
\min \end{array}$ & $\begin{array}{l}\text { Determination of NED characteristics helps } \\
\text { to predict the subjective experiences, } \\
\text { but the nature of the relation between } \\
\text { subjective and objective findings is complex } \\
\text { and depends on several NED-, user- and } \\
\text { task-related features. }\end{array}$ \\
\hline
\end{tabular}

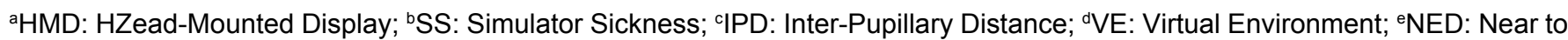
Eye Display; 'VIMS: Visually-Induced Motion sickness. 
ing data from multiple independent studies, this study allowed for a broad review and large population sample size in assessing the role of HMDs in visual discomfort. Furthermore, we systematically reviewed factors that might potentially affect the role of HMDs in visual discomfort. These factors included the characteristics of the systems, the participants (i.e., gender), and the tasks (i.e., duration, vection, and content).

\section{Methods}

\section{Study selection}

We performed an extensive and systematic review of scientific literature. The database search included Medline/PubMed (US National Institutes of Health/National Library of Medicine), Embase (Elsevier), ProQuest Central, ACM Digital Library (Association for Computing Machinery), and IEEE Xplore Digital Library (Institute of Electrical and Electronics Engineers). These databases were searched using the following keywords: VR, virtual environment (VE), HMDs, VIMS, SS, SSQ, VSQ, visual fatigue, and visual problems.
Only papers from peer-reviewed journals and large national conference proceedings were selected for inclusion in our study. For the relevant trials lacking data, we also attempted to contact the corresponding author by email for further unpublished but potentially relevant data; none of these contacts resulted in receipt of additional data. Unpublished data and abstracts were not included. No language restrictions were imposed.

The inclusion criteria consisted of any of the following: (1) Human studies evaluating visual system-related problems in HMD-based VE, (2) Studies involving self-reported questionnaires (SSQ and VSQ). Studies for visual problems without HMD-based VE, case studies with fewer than three participants, or studies without enough data to evaluate the impact of HMDs on visual discomfort were excluded.

\section{Evaluation methods of HMD-induced VIMS and vi- sual discomfort}

Visually Induced Motion Sickness (VIMS) can be measured by psychological and physiological methods. The

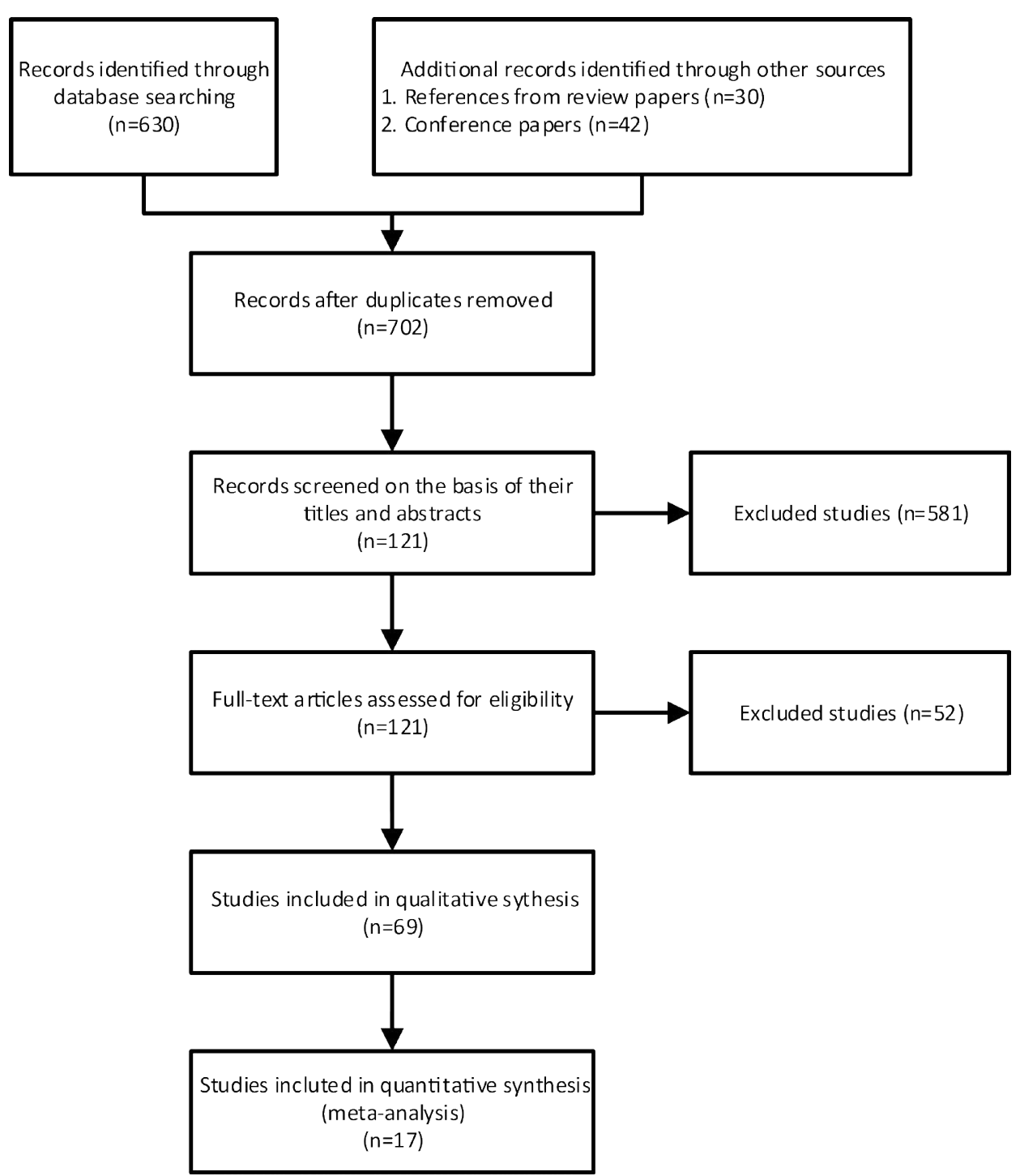

Figure 1: A forest plot diagram of mean change of the total severity score of simulator sickness questionnaire (SSQT) in pre- and post-HMDs exposure $\left(\mathrm{Chi}^{2}=\right.$ chi-square statistic; $\mathrm{Cl}=$ confidence interval; $\mathrm{df}=$ degrees of freedom; $\mathrm{I}^{2}=\mathrm{I}$-square heterogeneity statistic; IV = inverse variance; $\mathrm{SE}=$ standard error; $P=P$ value; $Z=Z$-statistic). 
Simulator Sickness Questionnaire (SSQ), a self-reported measurement, is a well-known psychological method and the gold standard for measuring the extent of VIMS $[4,55]$. The questionnaire consists of three components: nausea (SSQN), disorientation (SSQD), and oculomotor symptoms (SSQO). The total score of SSQ (SSQT) is an aggregate score of the three components.

The SSQ contains 16 items (i.e general disomfot, fatigue, eye strain, nausea), and each item is scored on a 4-point scale in which $0=$ none, $1=$ slight, $2=$ moderate and $3=$ severe [56]. Given that the discomfort caused by HMDs is often connected to visual symptoms, the $\mathrm{Vi}$ sual Strain Questionnaire (VSQ), a more detailed visual strain-related questionnaire, was used to measure the severity of eyestrain symptoms (e.g. tired, sore or aching, irritated, watering or runny, dry, hot and burning eyes; blurred or double vision; and general visual discomfort) [57]. 57 These symptoms of eyestrain are also often connected to computer vision syndrome [58-61]. In this study, the SSQ and VSQ were used to verify the occurrence of VIMS. Figure 1, Figure 2, Figure 3, and Figure 4 compare the mean score of SSQT, SSQO, and VSQ

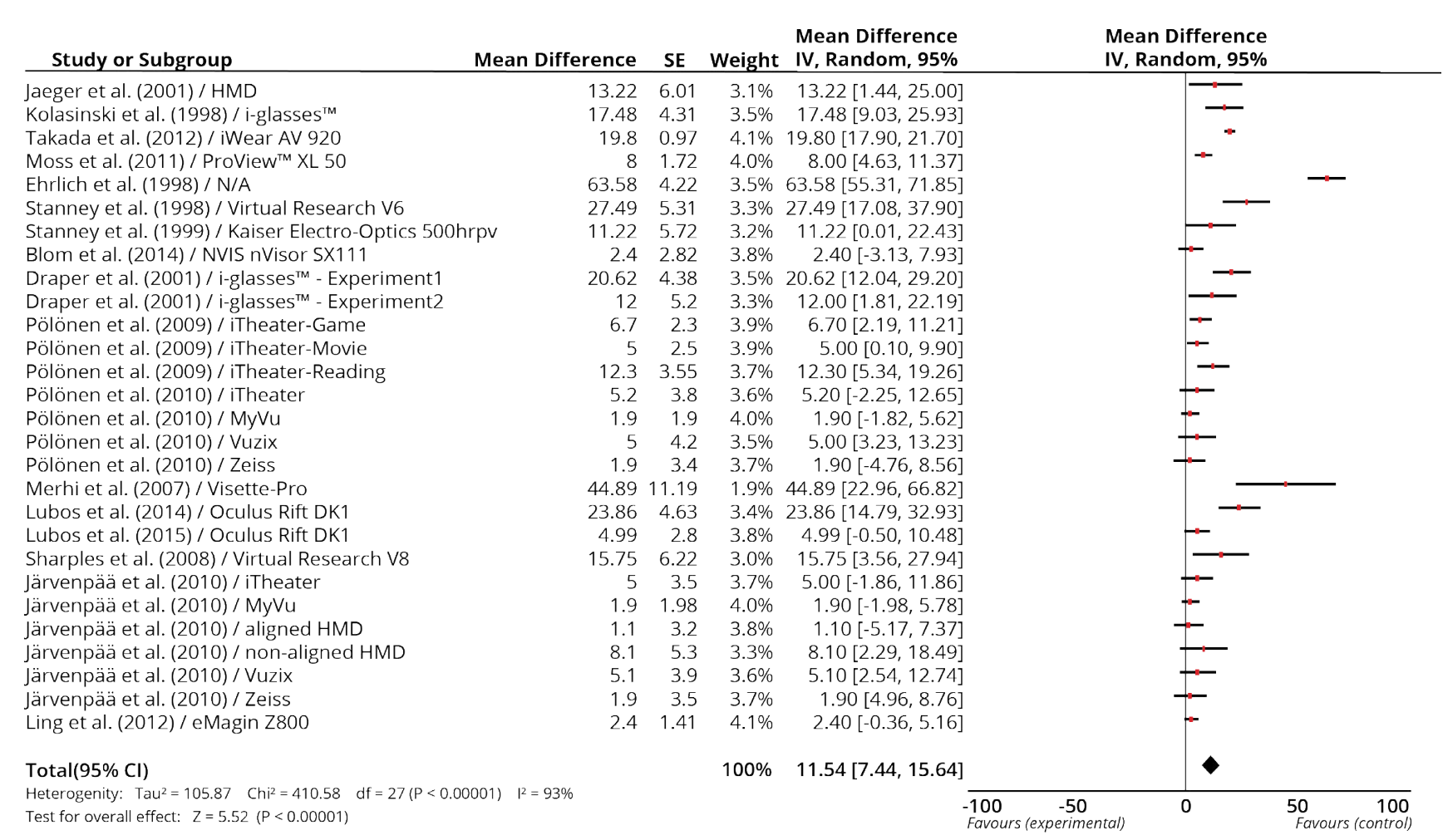

Figure 2: A forest plot diagram of mean change of the oculomotor scores of a simulator sickness questionnaire (SSQO) in pre- and post-HMDs exposure (abbreviations are the same as those in Figure 1).

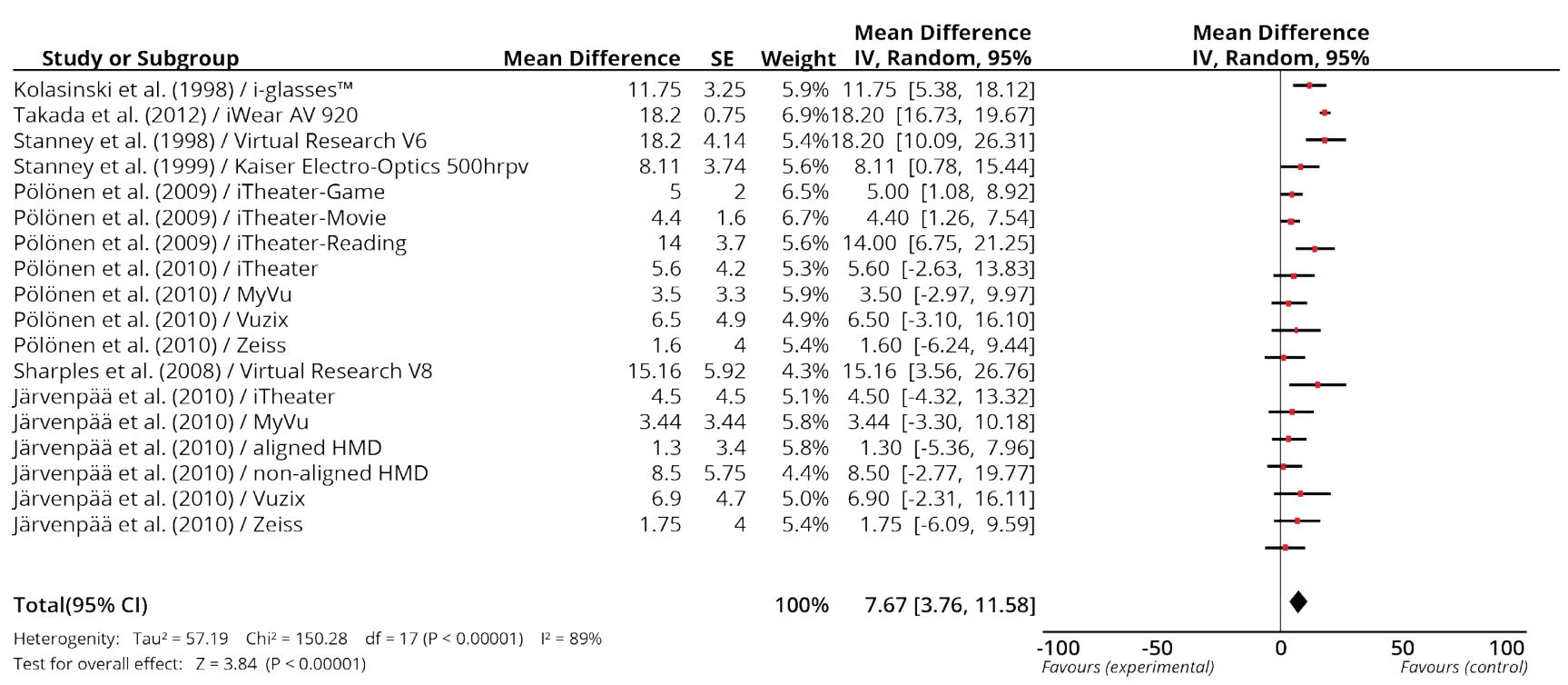

Figure 3: A forest plot diagram of mean change of the scores of visual strains questionnaire (VSQ) in pre- and post-HMDs exposure (abbreviations are the same as those in Figure 1). 


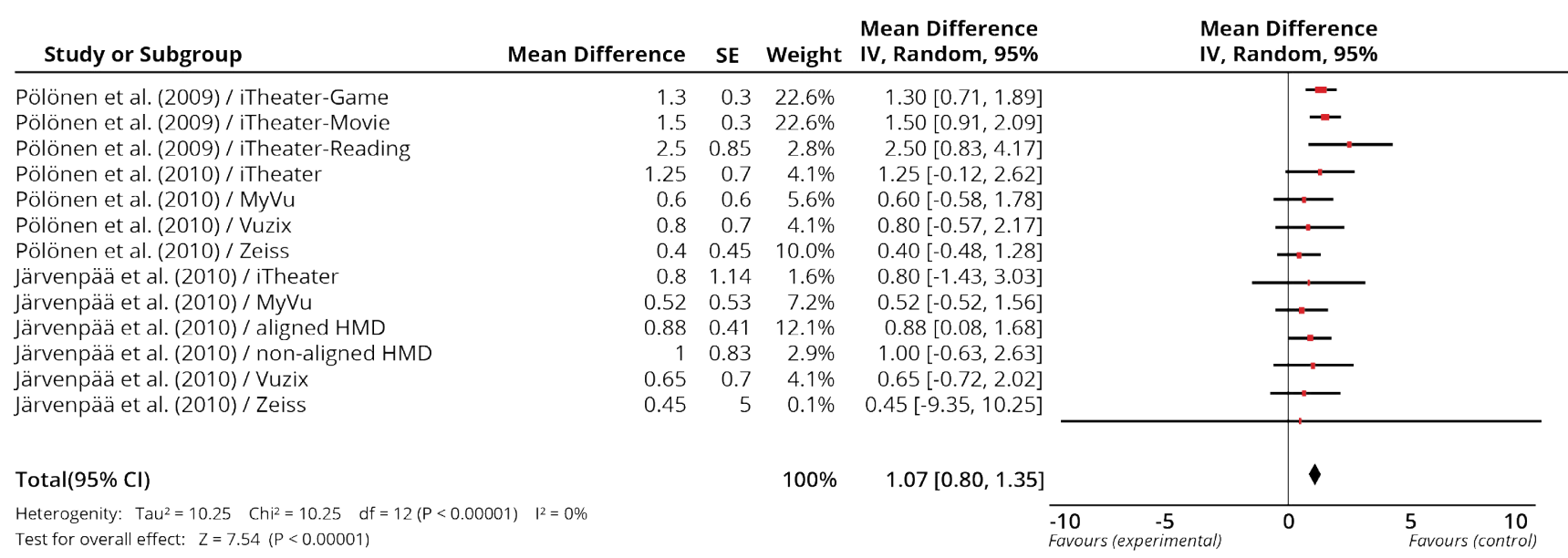

Figure 4: A forest plot diagram of sensitivity analyses of the mean change of the total severity score of SSQT in pre- and postHMDs exposure (abbreviations are the same as those in Figure 1).

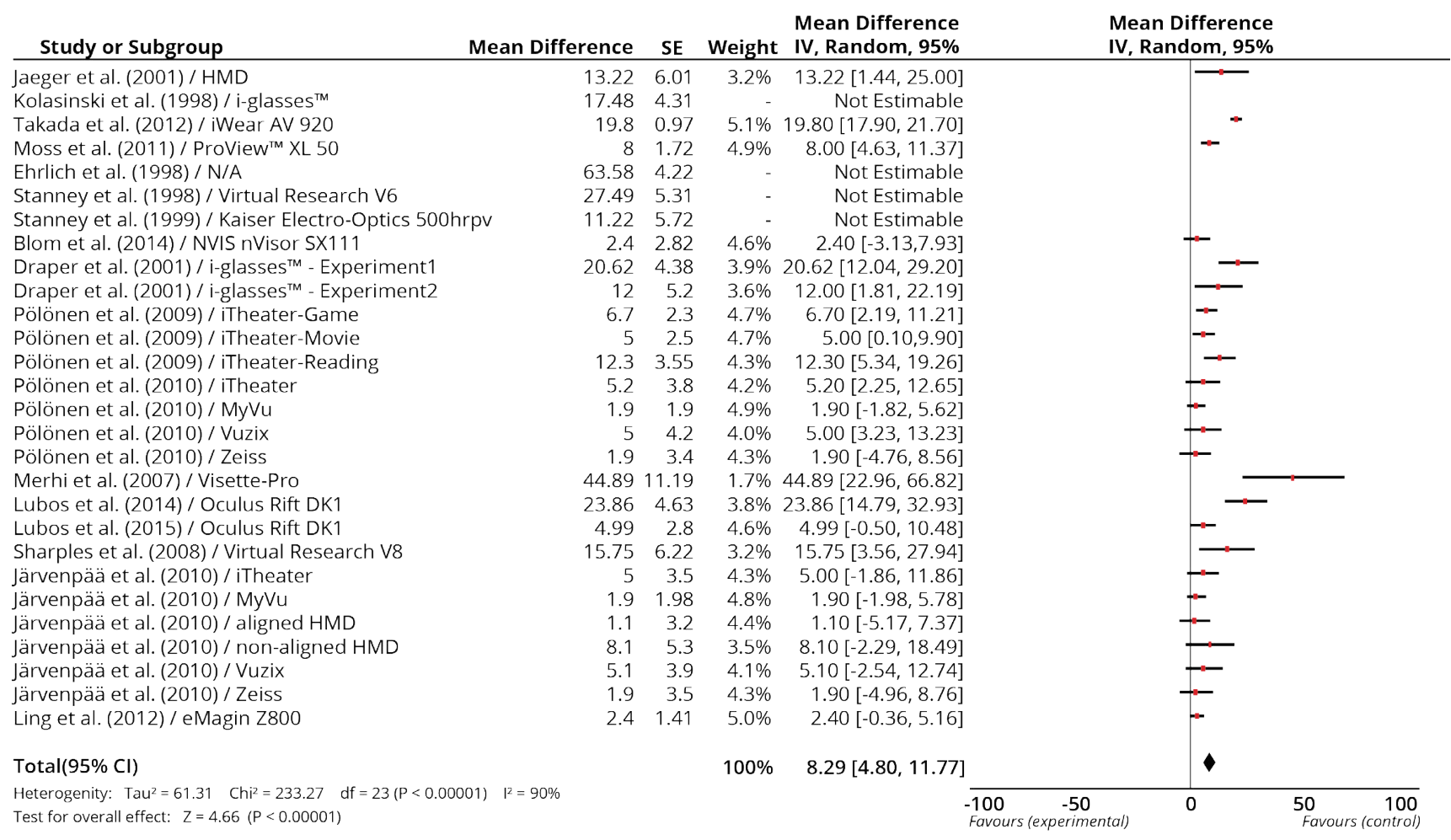

Figure 5: The flow chart of the process of article selection.

respectively between the various studies analyzed.

\section{Procedure}

The following variables listed below were used for primary outcomes. Mean change refers to the difference in SSQT scores between difference HMD devices (i.e. oculus rift versus FOVE).

(1) Mean change in symptom scores between different HMD-based VE.

(2) Comparison of mean change in symptom scores between HMDs and other traditional displays.

The visual impact of HMDs was used as the effect size in the meta-analysis. For multiple session VE exposure studies, we used only the data from the first VE exposure session in order to perform a between-group analysis. For studies with multiple measures of visual discomfort, we included only the SSQ and VSQ outcomes in the meta-analysis.

\section{Statistical analysis}

All statistical analyses were performed with Review Manager Version 5.3 (The Cochrane Collaboration, Oxford, England), using two-tailed $p$ values and a $95 \%$ Confidence Interval $(\mathrm{Cl})$. For generic inverse variance outcomes, the mean difference was analyzed. Meta regression was performed, and heterogeneity was explored using the $Q$ test with calculating 12 , indicating the percentage of variability due to heterogeneity rather than to chance. 12 values of $50 \%$ or more were considered 
substantial heterogeneity. The fixed-effects model was used to pool the data. A random-effects model was applied when $P<0.1$ in the test for heterogeneity, and the fixed-effects model was used for other cases [62].

\section{Results}

\section{Results of database search}

Figure 5 shows the flow chart of the selection process for the reviewed studies. Of 69 potentially relevant studies identified through the electronic search, 34 publications met all the inclusion criteria. After excluding 17 articles because specific data for SSQ or VSQ were not provided, 17 studies with 1040 participants remained for inclusion in the meta-analysis. The smallest sample size in an included article was twelve [47], and the largest was 232 [39]. All 17 studies were published between 1998 and 2015. Eight were performed in the USA; three in Finland; two in Germany; and one each in the United Kingdom, Japan, Spain, and the Netherlands.

\section{Characteristics and quality of trials}

Table 2 provides a description of the pre- versus post-exposure mean score changes of SSQT, SSQO and VSQ. These were analyzed in seventeen, seven, and three studies, respectively. In three studies, the mean SSQT and SSQO score changes in exposure to HMDs and traditional displays also were included in the meta-analysis.

\section{Effect of HMDs on VIMS and visual discomfort}

The forest plots show that the visual discomfort was significantly different in pre- versus post-VR exposure (Figure 1, Figure 2, and Figure 3). The results show mean difference of 11.54 (95\% $\mathrm{Cl} 7.44$ to $15.64 ; \mathrm{P}<0.00001)$, $7.67(95 \% \mathrm{Cl} 3.76$ to $11.58 ; \mathrm{P}=0.0001)$ and $1.07(95 \% \mathrm{Cl}$ 0.8 to $1.35 ; \mathrm{P}<0.00001$ ) for the SSQT, SSQO and VSQ, respectively.

In order to investigate the possible role of publication year, we undertook a sensitivity analysis by excluding the four studies published before 2000 . Older publications assessed older HMDs; consequently, their results may have been skewed in favor of greater VIMS. This analysis showed a mean difference of $8.29(95 \% \mathrm{Cl}$ 4.80 to $11.77 ; \mathrm{P}<0.00001$ ) for SSQT in pre- versus postVR exposure (Figure 4).

\section{Comparison of HMD exposure versus traditional displays}

Only four studies provided adequate information for meta-analysis of visual discomfort in HMDs compared to traditional displays (i.e., TV, desktop computer displays, or other 2D viewing condition) $[37,39,43,54]$. The forest plots show that the mean differences of SSQT and SSQO in HMDs versus traditional displays were 3.62 (95\% Cl 1.47 to $5.78 ; \mathrm{P}=0.001)$, and $4.78(95 \% \mathrm{Cl} 1.51$ to $8.05 ; \mathrm{P}=0.004$ ) respectively; these results were statistically significant (Figure 6 and Figure 7).

\begin{tabular}{|c|c|c|c|c|c|c|c|c|c|c|}
\hline \multirow[b]{2}{*}{ Study or Subgroup } & \multicolumn{3}{|c|}{ HMDs } & \multicolumn{4}{|c|}{ Traditional Displays } & \multirow{2}{*}{$\begin{array}{l}\text { Mean Difference } \\
\text { IV, Fixed, } 95 \% \mathrm{Cl}\end{array}$} & \multirow{2}{*}{$\begin{array}{l}\text { Mean Difference } \\
\text { IV, Fixed, } 95 \% \mathrm{Cl}\end{array}$} & \\
\hline & Mean & SD & Total & Mean & SD & Total & Weight & & & \\
\hline Pölönen et al. (2010) / iTheater & 5.2 & 16.56 & 19 & -0.4 & 9.84 & 20 & $6.3 \%$ & $5.60[-3.00,14.20]$ & & \\
\hline Pölönen et al. (2010) / MyVu & 1.9 & 8.5 & 20 & -0.4 & 9.84 & 20 & $14.3 \%$ & $2.30[-3.40,8.00]$ & & \\
\hline Pölönen et al. (2010) / Vuzix & 5 & 18.78 & 20 & -0.4 & 9.84 & 20 & $5.4 \%$ & $5.40[-3.89,14.69]$ & & \\
\hline Pölönen et al. (2010) / Zeiss & 1.9 & 14.42 & 18 & -0.4 & 9.84 & 20 & $7.4 \%$ & $2.30[-5.64,10.24]$ & & \\
\hline Sharples et al. (2008) / Virtual Research V8 & 15.75 & 24.51 & 19 & 5.51 & 15.83 & 18 & $2.7 \%$ & $10.24[-2.99,23.47]$ & & \\
\hline Järvenpää et al. (2010) / iTheater & 5 & 15.65 & 20 & -0.5 & 10.73 & 20 & $6.7 \%$ & $5.50[-2.82,13.82]$ & & \\
\hline Järvenpää et al. (2010) / MyVu & 1.9 & 8.85 & 20 & -0.5 & 10.73 & 20 & $12.5 \%$ & $2.40[-3.70,8.50]$ & & \\
\hline Järvenpää et al. (2010) / aligned HMD & 1.1 & 14.31 & 20 & -0.5 & 10.73 & 20 & $7.6 \%$ & $1.60[-6.24,9.44]$ & & \\
\hline Järvenpää et al. (2010) / non-aligned HMD & 8.1 & 23.7 & 20 & -0.5 & 10.73 & 20 & $3.6 \%$ & $8.60[-2.80,20.00]$ & & \\
\hline Järvenpää et al. (2010) / Vuzix & 5.1 & 17.44 & 20 & -0.5 & 10.73 & 20 & $5.8 \%$ & $5.60[-3.37,14.57]$ & & \\
\hline Järvenpää et al. (2010) / Zeiss & 1.9 & 15.65 & 20 & -0.5 & 10.73 & 20 & $6.7 \%$ & $2.40[-5.92,10.72]$ & & \\
\hline Ling et al. (2012) / eMagin Z800 & 2.4 & 13.04 & 86 & -0.57 & 17.95 & 86 & $21.1 \%$ & $2.97[-1.72,7.66]$ & & \\
\hline Total $(95 \% \mathrm{Cl})$ & & & 302 & & & 304 & $100 \%$ & $8.29[4.80,11.77]$ & & \\
\hline $\begin{array}{l}\text { Heterogenity: } \mathrm{Chi}^{2}=3.30 \quad \mathrm{df}=11(\mathrm{P}<0.99) \quad \mathrm{I}^{2}=0 \% \\
\text { Test for overall effect: } Z=3.29(\mathrm{P}<0.0010)\end{array}$ & & & & & & & & & $\begin{array}{l}0 \\
\text { ental) }\end{array}$ & $10 \quad 20$ \\
\hline
\end{tabular}

Figure 6: A forest plot diagram of HMDs versus the traditional displays (TV, desktop, or other 2D viewing condition) for the mean change of the total severity score of SSQT (abbreviations are the same as those in Figure 1).

\begin{tabular}{|c|c|c|c|c|c|c|c|c|c|c|}
\hline \multirow[b]{2}{*}{ Study or Subgroup } & \multicolumn{3}{|c|}{ HMDs } & \multicolumn{4}{|c|}{ Traditional Displays } & \multirow{2}{*}{$\begin{array}{l}\text { Mean Difference } \\
\text { IV, Fixed, } 95 \% \mathrm{CI}\end{array}$} & \multirow{2}{*}{$\begin{array}{l}\text { Mean Difference } \\
\text { IV, Fixed, } 95 \% \mathrm{CI}\end{array}$} & \\
\hline & Mean & SD & Total & Mean & SD & Total & Weight & & & \\
\hline Pölönen et al. (2010) / iTheater & 5.6 & 18.31 & 19 & -0.5 & 16.01 & 20 & $9.1 \%$ & $6.10[-4.72,16.92]$ & & \\
\hline Pölönen et al. (2010) / MyVu & 3.5 & 14.76 & 20 & -0.5 & 16.01 & 20 & $11.7 \%$ & $4.00[-5.54,13.54]$ & & \\
\hline Pölönen et al. (2010) / Vuzix & 6.5 & 21.91 & 20 & -0.5 & 16.01 & 20 & $7.6 \%$ & $7.00[-4.89,18.89]$ & & \\
\hline Pölönen et al. (2010) / Zeiss & 1.6 & 16.97 & 18 & -0.5 & 16.01 & 20 & $9.7 \%$ & $2.10[-8.42,12.62]$ & & \\
\hline Sharples et al. (2008) / Virtual Research V8 & 15.16 & 24.83 & 19 & 6.78 & 17.41 & 18 & $5.7 \%$ & $8.38[-5.38,22.14]$ & & \\
\hline Järvenpää et al. (2010) / iTheater & 4.5 & 20.12 & 20 & -0.62 & 15.56 & 20 & $8.6 \%$ & $5.12[-6.03,16.27]$ & & \\
\hline Järvenpää et al. (2010) / MyVu & 3.44 & 15.38 & 20 & -0.62 & 15.56 & 20 & $11.6 \%$ & $4.06[-5.53,13.65]$ & & \\
\hline Järvenpää et al. (2010) / aligned HMD & 1.3 & 15.21 & 20 & -0.62 & 15.56 & 20 & $11.8 \%$ & $1.92[-7.62,11.46]$ & & \\
\hline Järvenpää et al. (2010) / non-aligned HMD & 8.5 & 25.71 & 20 & -0.62 & 15.56 & 20 & $6.2 \%$ & $9.12[-4.05,22.29]$ & & \\
\hline Järvenpää et al. (2010) / Vuzix & 6.9 & 21.02 & 20 & -0.62 & 15.56 & 20 & $8.1 \%$ & $7.52[-3.94,18.98]$ & & \\
\hline Järvenpää et al. (2010) / Zeiss & 1.75 & 17.89 & 20 & -0.62 & 15.56 & 20 & $9.9 \%$ & $2.37[-8.02,12.76]$ & & \\
\hline Total $(95 \% \mathrm{Cl})$ & & & 216 & & & 218 & $100 \%$ & $8.29[1.51,8.05]$ & & \\
\hline $\begin{array}{l}\text { Heterogenity: Chi }=1.94 \quad \mathrm{df}=10(\mathrm{P}<1.00) \quad \mathrm{I}^{2}=0 \% \\
\text { Test for overall effect: } Z-2.87(\mathrm{P}<0.004)\end{array}$ & & & & & & & & & $\begin{array}{l}0 \\
\text { ental) }\end{array}$ & $10 \quad 20$ \\
\hline
\end{tabular}

Figure 7: A forest plot diagram of HMDs versus the traditional displays (TV/desktop) for the mean change of the oculomotor scores of SSQO (abbreviations are the same as those in Figure 1). 
Table 3: Experimental studies investigating causative factors of HMD-induced motion sicknes.

\begin{tabular}{|c|c|c|c|}
\hline $\begin{array}{l}\text { Number of } \\
\text { Studies }\end{array}$ & Groups & $\begin{array}{l}\text { Variables } \\
\text { investigated }\end{array}$ & References \\
\hline \multirow[t]{3}{*}{26} & $\begin{array}{l}\text { (1) Studies } \\
\text { investigating } \\
\text { variables } \\
\text { related to } \\
\text { systems }\end{array}$ & $\begin{array}{l}\text { Display's field-of- } \\
\text { view }\end{array}$ & Moss [34], Draper [51] \\
\hline & & System time delay & Moss [34], Draper [51], Nelson [64], St. Pierre [65] \\
\hline & & $\begin{array}{l}\text { Optical } \\
\text { characteristic }\end{array}$ & $\begin{array}{l}\text { Aykent [66] } 66 \text { Peli [14], Kooi [67], Sheedy [18], Kuze [17], Moss [68], } \\
\text { Ehrlich [69], Häkkinenl [70], Häkkinen [71] Moffitt [72], Kim [73], Pölönen } \\
\text { [37], Pölönen [74], Pölönen [52], Howarth [20], Howarth [19], Kozulin [21], } \\
\text { Vlad [75], Sharples [54], Nichols [22], Järvenpää [38], Järvenpää [39] }\end{array}$ \\
\hline \multirow[t]{4}{*}{20} & $\begin{array}{l}\text { (2) Studies } \\
\text { investigating } \\
\text { variables } \\
\text { related to } \\
\text { individuals }\end{array}$ & Age, gender & $\begin{array}{l}\text { Jaeger [48], Kolasinski [49], Häkkinen [69], Stanney [33], Kozulin [21], } \\
\text { Mourant [76] }\end{array}$ \\
\hline & & Posture stability & Häkkinen [69], Smart [77], Owen [78], Cobb [79], Stoffregen [80] \\
\hline & & Habituation & Regan [81], Hill [82], Howarth [83], Kennedy [84] \\
\hline & & Personality traits & $\begin{array}{l}\text { Takada [85], Ehrlich [50], Kotulak [86], Ehrlich [87], Kutsuna [88], } \\
\text { Morse [89], Stoffregen [80] }\end{array}$ \\
\hline \multirow[t]{6}{*}{28} & $\begin{array}{l}\text { (3) Studies } \\
\text { investigating } \\
\text { variables } \\
\text { related to task } \\
\text { characteristics }\end{array}$ & $\begin{array}{l}\text { Dynamic or static } \\
\text { stimuli }\end{array}$ & Jaeger [48], Ehrlich [50] \\
\hline & & Vection & $\begin{array}{l}\text { Davis [90], Jang [91], Kuze [17], Smart [77], So [92], So [93], Mourant } \\
\text { [76], Lo [94] }\end{array}$ \\
\hline & & Duration & $\begin{array}{l}\text { Jaeger [48], Lampton [95], Kuze [17], Moss [34], Häkkinen [70], } \\
\text { Stanney [32], Kozulin [21], Kennedy [84], Ames [25], Rushton [24], } \\
\text { Steinicke [96], Järvenpää [39], Aaltonen [26] }\end{array}$ \\
\hline & & Viewing angle & Mon-Williams [30], Pölönen [97] \\
\hline & & Task content & Jaeger [48], Häkkinen [70], Pölönen [52], Nelson [64], Järvenpää [39] \\
\hline & & Sitting or standing & Merhi [53], Stoffregen [80], Nichols [22] \\
\hline
\end{tabular}

Table 4: Eye symptoms related to head mounted display exposure.

\begin{tabular}{|c|c|c|c|c|c|c|}
\hline Author & Country & $\begin{array}{l}\text { Subjects } \\
\text { Male } \\
\text { Female }\end{array}$ & $\begin{array}{l}\text { Mean- age } \\
\text { Age- range } \\
\text { (years) }\end{array}$ & $\begin{array}{l}\text { Head Mounted } \\
\text { Displays }\end{array}$ & $\begin{array}{l}\text { Evaluation } \\
\text { methods }\end{array}$ & Results \\
\hline Kooi [67] & $\begin{array}{l}\text { Nether- } \\
\text { lands }\end{array}$ & 8 & Not Given & $\begin{array}{l}\text { Virtual } \mathrm{I} / \mathrm{O} \\
\text { i-glasses }^{\mathrm{TM}} \\
\text { Vision Sport } \\
\text { monocular }\end{array}$ & $\begin{array}{l}\text { Objective } \\
\text { measurement }\end{array}$ & $\begin{array}{l}\text { The scores of the accommodative facility } \\
\text { after viewing the Vision Sport HMD were } \\
\text { reduced to nearly half their value, showing } \\
\text { significant strain. The Virtual io HMD scores } \\
\text { were intermediate, the monocular version } \\
\text { being more straining than the binocular } \\
\text { version. All subjects showed more eyestrain } \\
\text { with the monocular systems. }\end{array}$ \\
\hline Ehrlich [69] & USA & $\begin{array}{l}48 \\
36 \mathrm{M} \\
12 \mathrm{~F}\end{array}$ & $\begin{array}{l}23.6 \\
(18-50)\end{array}$ & $\begin{array}{l}\text { Virtual Research } \\
\text { Fight Helmet }\end{array}$ & SSQ & $\begin{array}{l}\text { The stereoscopic condition produced } \\
\text { greater simulator sickness than the bi- } \\
\text { ocular condition. }\end{array}$ \\
\hline Howarth [19] & UK & $\begin{array}{l}20 \\
16 \mathrm{M} \\
4 \mathrm{~F}\end{array}$ & $\begin{array}{l}28 \\
(19-42)\end{array}$ & $\begin{array}{l}\text { Virtual I/O } \\
\text { i-glasses }\end{array}$ & $\begin{array}{l}\text { Subjective } \\
\text { questionnaire }\end{array}$ & $\begin{array}{l}\text { The use of HMDs as personal viewing } \\
\text { devices more readily induced the specific } \\
\text { symptoms of virtual simulation sickness. }\end{array}$ \\
\hline Peli [14] & USA & $\begin{array}{l}37 \\
21 \mathrm{M} \\
16 \mathrm{~F}\end{array}$ & $18-49$ & $\begin{array}{l}\text { Virtual } \mathrm{I} / \mathrm{O} \\
\text { i-glasses }\end{array}$ & $\begin{array}{l}\text { Subjective } \\
\text { questionnaire } \\
\text { Objective } \\
\text { measurement }\end{array}$ & $\begin{array}{l}\text { No functional differences were found } \\
\text { between HMD and CRT' }{ }^{\text {}} \text {. Subjective } \\
\text { comfort found a statistically significant } \\
\text { difference in the impression of comfort } \\
\text { between the CRT and the HMD in } \\
\text { stereoscopic mode. }\end{array}$ \\
\hline $\begin{array}{l}\text { Nichols } \\
\text { [22] }\end{array}$ & UK & $\begin{array}{l}9 \\
6 \mathrm{M} \\
3 \mathrm{~F}\end{array}$ & 25 & $\begin{array}{l}\text { Virtuality Visette } \\
2, \text { Virtual } \mathrm{i} / \mathrm{O} \\
\text { i-glasses }^{\mathrm{TM}} \\
\text { Division }^{\mathrm{d} \text { Visor }}\end{array}$ & $\begin{array}{l}\text { Subjective } \\
\text { questionnaire }\end{array}$ & $\begin{array}{l}\text { Participants experienced different levels of } \\
\text { discomfort in different systems. Ergonomics } \\
\text { of HMDs were potential causes of } \\
\text { discomfort. }\end{array}$ \\
\hline
\end{tabular}




\begin{tabular}{|c|c|c|c|c|c|c|}
\hline Howarth [20] & UK & $\begin{array}{l}41 \\
32 \mathrm{M} \\
9 \mathrm{~F}\end{array}$ & $\begin{array}{l}27 \\
(19-56)\end{array}$ & $\begin{array}{l}\text { Virtual } \mathrm{I} / \mathrm{O} \\
\text { i-glasses }^{\mathrm{TM}} \\
\text { Virtuality Visette } \\
\text { 2, Division dVisor }\end{array}$ & $\begin{array}{l}\text { Objective } \\
\text { measurement }\end{array}$ & $\begin{array}{l}\text { The use of HMDs in immersive VR can } \\
\text { lead to changes within the oculomotor } \\
\text { system. The Virtual I-Glasses and Division } \\
\text { systems induced exophoric changes (eyes } \\
\text { turning outwards), Virtuality system induced } \\
\text { esophoric changes (eyes turning inwards). }\end{array}$ \\
\hline $\begin{array}{l}\text { Sheedy } \\
{[18]}\end{array}$ & USA & 22 & $\begin{array}{l}22 \pm 5.9(18 \\
-39)\end{array}$ & $\begin{array}{l}\text { Inviso eCase, } \\
\text { Inviso eShades }\end{array}$ & $\begin{array}{l}\text { Subjective } \\
\text { questionnaire } \\
\text { Objective } \\
\text { measurement }\end{array}$ & $\begin{array}{l}\text { Symptoms of eyestrain and blurry vision } \\
\text { were significantly higher on monocular } \\
\text { virtual than on other displays. No significant } \\
\text { changes in visual acuity or heterophoria } \\
\text { occurred with any of the displays. Motion- } \\
\text { related symptoms with the head mounted } \\
\text { near-eye display were not significantly } \\
\text { different from those observed with other } \\
\text { displays tested. }\end{array}$ \\
\hline $\begin{array}{l}\text { Häkki- } \\
\text { Nen [70] }\end{array}$ & Finland & $\begin{array}{l}60 \\
36 \mathrm{M} \\
24 \mathrm{~F}\end{array}$ & $\begin{array}{l}26.8 \\
(18-41)\end{array}$ & $\begin{array}{l}\text { Olympus EyeTrek } \\
\text { FMD-700 }\end{array}$ & $\begin{array}{l}\text { Simulator } \\
\text { Sickness } \\
\text { Questionnaire } \\
\text { Visual } \\
\text { Symptom } \\
\text { Questionnaire }\end{array}$ & $\begin{array}{l}\text { The stereoscopic condition produced } \\
\text { slightly increased postural sway and } \\
\text { sickness symptoms for } 20-30 \text { min after } \\
\text { HMD use. }\end{array}$ \\
\hline $\begin{array}{l}\text { Häkki-nen } \\
\text { [71] }\end{array}$ & Finland & 60 & $\begin{array}{l}27.8 \\
(19-48)\end{array}$ & $\begin{array}{l}\text { Olympus EyeTrek } \\
\text { FMD-700 }\end{array}$ & $\begin{array}{l}\text { Simulator } \\
\text { Sickness } \\
\text { Questionnaire }\end{array}$ & $\begin{array}{l}\text { No significant differences in sickness } \\
\text { symptoms compared to ordinary display } \\
\text { and the virtual display in non-stereoscopic } \\
\text { mode. In stereoscopic condition the eye } \\
\text { strain and disorientation symptoms were } \\
\text { significantly elevated compared to the } \\
\text { ordinary display. }\end{array}$ \\
\hline Kuze [17] & Japan & 104 & $(17-32)$ & $\begin{array}{l}\text { Sony Glasstron } \\
\text { PLM-50 }\end{array}$ & $\begin{array}{l}\text { Subjective } \\
\text { questionnaire }\end{array}$ & $\begin{array}{l}\text { Viewing stereoscopic images caused visual } \\
\text { fatigue. }\end{array}$ \\
\hline Moss [68] & USA & $\begin{array}{l}10 \\
2 \mathrm{M} \\
8 \mathrm{~F}\end{array}$ & 20.6 & ProView XL50 & $\begin{array}{l}\text { Simulator } \\
\text { Sickness } \\
\text { Questionnaire }\end{array}$ & $\begin{array}{l}\text { Peak Simulator } \\
\text { Sickness Questionnaire scores were } \\
\text { significantly higher when wearing an HMD } \\
\text { than when not wearing an HMD to view the } \\
\text { laboratory. }\end{array}$ \\
\hline $\begin{array}{l}\text { Sharp-les } \\
{[54]}\end{array}$ & UK & $\begin{array}{l}71 \\
38 \mathrm{M} \\
33 \mathrm{~F}\end{array}$ & Not Given & $\begin{array}{l}\text { Virtual research } \\
\text { V8 }\end{array}$ & $\begin{array}{l}\text { Simulator } \\
\text { Sickness } \\
\text { Questionnaire }\end{array}$ & $\begin{array}{l}\text { Higher reported symptoms in HMD } \\
\text { compared with desktop viewing (nausea) } \\
\text { and in HMD compared with reality } \\
\text { theatre viewing (nausea, oculomotor and } \\
\text { disorientation symptoms). }\end{array}$ \\
\hline $\begin{array}{l}\text { Kozulin } \\
{[21]}\end{array}$ & Australia & $\begin{array}{l}60 \\
29 \mathrm{M} \\
31 \mathrm{~F}\end{array}$ & $\begin{array}{l}11 \\
(5-16)\end{array}$ & $\begin{array}{l}\text { Micro-Optical } \\
\text { Binocular Viewer }\end{array}$ & $\begin{array}{l}\text { Subjective } \\
\text { questionnaire } \\
\text { Objective } \\
\text { measurent }\end{array}$ & $\begin{array}{l}\text { In children aged } 5 \text { to } 16 \text { years, virtual } \\
\text { imagery viewing with the Binocular Viewer } \\
\text { had few additional adverse effects when } \\
\text { compared to viewing a more conventional } \\
\text { high definition television display. }\end{array}$ \\
\hline $\begin{array}{l}\text { Järven } \\
\text { Pää [38] }\end{array}$ & Finland & 120 & Not Given & $\begin{array}{l}\text { iTheater, MyVu, } \\
\text { Vuzix, Zeiss }\end{array}$ & $\begin{array}{l}\text { Simulator } \\
\text { Sickness } \\
\text { Questionnaire } \\
\text { Visual } \\
\text { Symptom } \\
\text { Questionnaire }\end{array}$ & $\begin{array}{l}\text { Small interocular differences in biocular } \\
\text { NEDs are not easily detected by humans, } \\
\text { but may still create visual fatigue. }\end{array}$ \\
\hline $\begin{array}{l}\text { Järven } \\
\text { Pää [39] }\end{array}$ & Finland & $\begin{array}{l}232 \\
123 M \\
109 F\end{array}$ & $\begin{array}{l}34.5 \\
(21-53)\end{array}$ & $\begin{array}{l}\text { Five unidentified } \\
\text { Head Mounted } \\
\text { Displays likely } \\
\text { including HMDs } \\
\text { from Järvenpää } \\
{[38]}\end{array}$ & $\begin{array}{l}\text { Simulator } \\
\text { Sickness } \\
\text { Questionnaire } \\
\text { Visual } \\
\text { Symptom } \\
\text { Questionnaire }\end{array}$ & $\begin{array}{l}\text { The determination of NED's characteristics } \\
\text { helped to predict the subjective } \\
\text { experiences, but the nature of the relation } \\
\text { between subjective and objective findings } \\
\text { was rather complex and depended on } \\
\text { several NED-, user-, and task-related } \\
\text { features. }\end{array}$ \\
\hline
\end{tabular}




\begin{tabular}{|c|c|c|c|c|c|c|}
\hline Pölönen [37] & Finland & $\begin{array}{l}97 \\
48 \mathrm{M} \\
49 \mathrm{~F}\end{array}$ & $\begin{array}{l}33.8 \\
(23-45)\end{array}$ & $\begin{array}{l}\text { iTheater, MyVu, } \\
\text { Vuzix, Zeiss } \\
\text { Cinemizer Plus }\end{array}$ & $\begin{array}{l}\text { Simulator } \\
\text { Sickness } \\
\text { Questionnaire } \\
\text { Visual } \\
\text { Symptom } \\
\text { Questionnaire }\end{array}$ & $\begin{array}{l}\text { In general sickness levels remained low } \\
\text { after } 40 \text { min of immersion. Better headset } \\
\text { fit, and light structure were related to } \\
\text { lower total workload, frustration and effort } \\
\text { levels, and to positive opinion change. } \\
\text { Higher visual quality and positive opinion } \\
\text { change were related to more pleasant task } \\
\text { experiences, whereas sickness and high } \\
\text { workload led to less pleasant outcomes. }\end{array}$ \\
\hline Pölönen [74] & Finland & $\begin{array}{l}20 \\
10 \mathrm{M} \\
10 \mathrm{~F}\end{array}$ & $\begin{array}{l}34.9 \\
(23-53)\end{array}$ & $\begin{array}{l}\text { iTheater BP4L, } \\
\text { Zeiss Cinemizer } \\
\text { Plus, Vuzix Wrap } \\
920\end{array}$ & $\begin{array}{l}\text { Simulator } \\
\text { Sickness } \\
\text { Questionnaire } \\
\text { Visual } \\
\text { Symptom } \\
\text { Questionnaire }\end{array}$ & $\begin{array}{l}\text { All near-to-eye displays induced eyestrain } \\
\text { and sickness symptoms, but the magnitude } \\
\text { of these symptoms varied according to } \\
\text { the device. The adverse symptoms were } \\
\text { related to problems with the display optics } \\
\text { and design, text layout, headset fit, use } \\
\text { context, and individual differences. }\end{array}$ \\
\hline Vlad [75] & France & $\begin{array}{l}102 \\
65 \mathrm{M} \\
37 \mathrm{~F}\end{array}$ & 25 & Prototype HMDs & $\begin{array}{l}\text { Simulator } \\
\text { Sickness } \\
\text { Questionnaire }\end{array}$ & $\begin{array}{l}\text { Different stereoscopic displays generated } \\
\text { different symptoms. }\end{array}$ \\
\hline Aykent [66] & France & $\begin{array}{l}14 \\
12 \mathrm{M} \\
2 \mathrm{~F}\end{array}$ & $24.4 \pm 2$ & OCULUS Rift & $\begin{array}{l}\text { Subjective } \\
\text { questionnaire } \\
\text { Objective } \\
\text { measurement } \\
\text { Modified } \\
\text { Simulator } \\
\text { Sickness } \\
\text { Questionnaire }\end{array}$ & $\begin{array}{l}\text { Oculus HMDs could cause more sickness } \\
\text { in driving simulators, such as Eco } 2 \\
\text { driving simulator, than medium field of } \\
\text { view systems. However, this type of HMD } \\
\text { may have provided better immersive } \\
\text { impressions than medium to large files of } \\
\text { view display systems. }\end{array}$ \\
\hline
\end{tabular}

aHMD: Head-Mounted Display; ${ }^{\mathrm{b}} \mathrm{CRT}$ : Cathode Ray Tube.

Table 5: Eye symptoms related to vection in a head mounted display environment.

\begin{tabular}{|c|c|c|c|c|}
\hline Study & HMD & Vection & $\begin{array}{l}\text { Immersion } \\
\text { times (minutes) }\end{array}$ & Eye symptom \\
\hline So [93] & $\begin{array}{l}\text { Virtual } \\
\text { Research VR4 }\end{array}$ & $\begin{array}{l}\text { 3D VEa viewing, E1: visual } \\
\text { scene oscillation in the yaw } \\
\text { axis (angular velocity was } \\
30^{\circ} / \text { second and the range } \\
\text { of oscillation was } \pm 60^{\circ} \text { ), E2: } \\
\text { visual scene was stationary. }\end{array}$ & 20 & $\begin{array}{l}\text { Total severity scores of } S^{b} \text { questionnaires and } \\
\text { three SS Questionnaire sub-scores increased } \\
\text { significantly after both conditions (with and } \\
\text { without scene movement); with the absence } \\
\text { of scene movement, these scores were } \\
\text { significantly less. }\end{array}$ \\
\hline Mourant [76] & $\begin{array}{l}\text { Virtual } \\
\text { Research VR8 }\end{array}$ & $\begin{array}{l}\text { 3D VE: virtual driving } \\
\text { simulator three types: } \\
\text { highway }\left(60 \mathrm{mph}^{\mathrm{c}}\right) \text {, rural }(60 \\
\text { mph), city }(25 \mathrm{mph})\end{array}$ & & $\begin{array}{l}\text { Participants in the highway }(60 \mathrm{mph}) \text { or rural } \\
\text { road ( } 60 \mathrm{mph}) \text { virtual environments reported } \\
\text { more symptoms than those in the city virtual } \\
\text { environment ( } 25 \mathrm{mph}) \text {. }\end{array}$ \\
\hline So [92] & $\begin{array}{l}\text { Virtual } \\
\text { Research VR4 }\end{array}$ & $\begin{array}{l}\text { 3D VE: Speeds of } 3.3,4.3 \\
5.9,7.9,9.5,23.6,29.6 \text {, and } \\
59.2 \mathrm{~m} / \mathrm{s}^{\mathrm{d}} \mathrm{RMS}^{\mathrm{e}} \text { in the fore- } \\
\text { and-aft axis }\end{array}$ & 30 & $\begin{array}{l}\text { Vection sensation and sickness symptoms } \\
\text { increased with increasing navigation speeds } \\
\text { from } 3 \mathrm{~m} / \mathrm{s} \text { to } 10 \mathrm{~m} / \mathrm{s} \text { RMS. Beyond } 10 \mathrm{~m} / \mathrm{s} \\
\text { RMS, both vection and sickness stabilized and } \\
\text { remained steady as speeds increased further to } \\
59 \mathrm{~m} / \mathrm{s} \text { RMS. }\end{array}$ \\
\hline Lo [94] & $\begin{array}{l}\text { Virtual } \\
\text { Research VR4 }\end{array}$ & $\begin{array}{l}\text { E1: Scene oscillations along } \\
\text { different axes (pitch, yaw, } \\
\text { roll or no oscillation), E2: } \\
\text { Without scene oscillations }\end{array}$ & 20 & $\begin{array}{l}\text { Nausea ratings and SS Questionnaire scores } \\
\text { increased at higher rates in the presence of } \\
\text { scene oscillations than with no oscillation. } \\
\text { Overall effects of oscillations along different } \\
\text { axes were not significant. }\end{array}$ \\
\hline Kuze [17] & $\begin{array}{l}\text { Glasstron PLM- } \\
50\end{array}$ & $\begin{array}{l}\text { E1: Shaky video, E2: } \\
\text { Stabilized video }\end{array}$ & 20 & $\begin{array}{l}\text { Change in eyestrain scores was higher when } \\
\text { viewing shaky video. }\end{array}$ \\
\hline Davis [90] & $\begin{array}{l}\text { Oculus Rift } \\
\text { DK } 1\end{array}$ & Two virtual roller coasters & 14 & $\begin{array}{l}\text { The more realistic roller coaster with higher } \\
\text { levels of visual flow had a significantly greater } \\
\text { chance of inducing sickness. }\end{array}$ \\
\hline
\end{tabular}

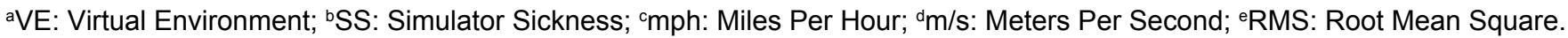




\section{Systematic review of the different influence fac- tors of HMD-induced visual discomfort}

The previous studies highlighted a number of factors that have the potential to cause stress to the visual system in HMD-based VR. It seems that the stress on the visual system is multifactorial [63] (Table 3). We identified several studies that reported the effects of HMDs from different influence factors. Among these studies, HMDs' optical characteristics (system features), participants' gender (individual characteristics), duration, vection, and task content (task characteristics) were systematically reviewed respectively (Table 4 , Table 5 , Figure 8 , Figure 9, and Figure 10).

\section{Discussion}

Advances in HMD technology have provided the potential for its widespread use in VR. However, VIMS, as an inherent problem, still remains an obstacle to public adoption and commercial development of this technology. HMD devices, such as Oculus Rift, HTC Vive, Sam- sung Gear, FOVE and Google DayDream have already entered the market, thus highlighting the importance of further research about VIMS. In our meta-analysis and systematic review, we have demonstrated through our data analysis the presence of significant visual discomfort after exposure to HMDs, when compared to traditional displays, and identified the potential moderating factors for this visual discomfort. To our knowledge, this is the first comprehensive summary and meta-analysis to address this issue.

Although the evaluation methods of HMD-induced visual problems varied between studies and in some studies the details were not provided, the results of this meta-analysis showed that regardless of the evaluation methods, the exposure to HMDs has been associated with significant visual discomfort. This meta-analysis of pre- and post-exposure questionnaires demonstrated significant associations between visual impact and the mean change scores of total severities of SS, oculomotor score of simulator sickness questionnaires scores
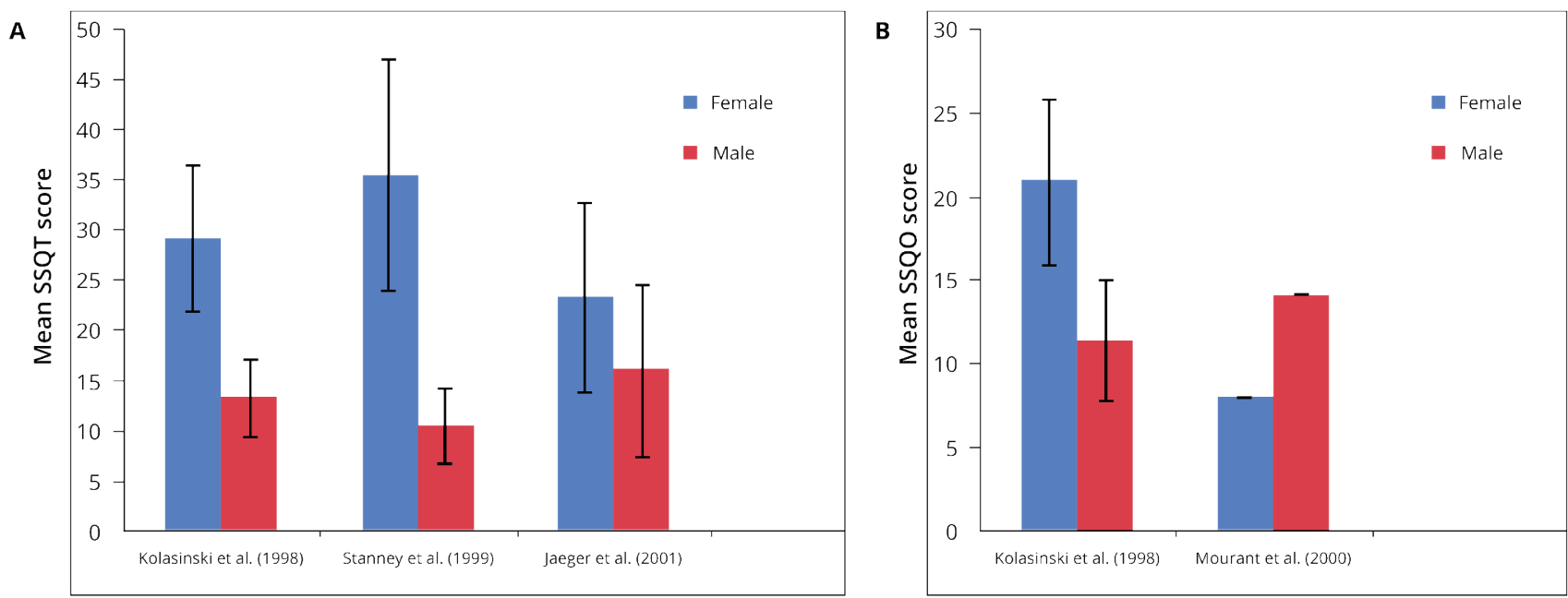

Figure 8: Mean SSQ scores by gender in different studies (higher scores = higher symptom severity). A: SSQT scores; B: SSQO scores. Error bars represent standard error of mean.
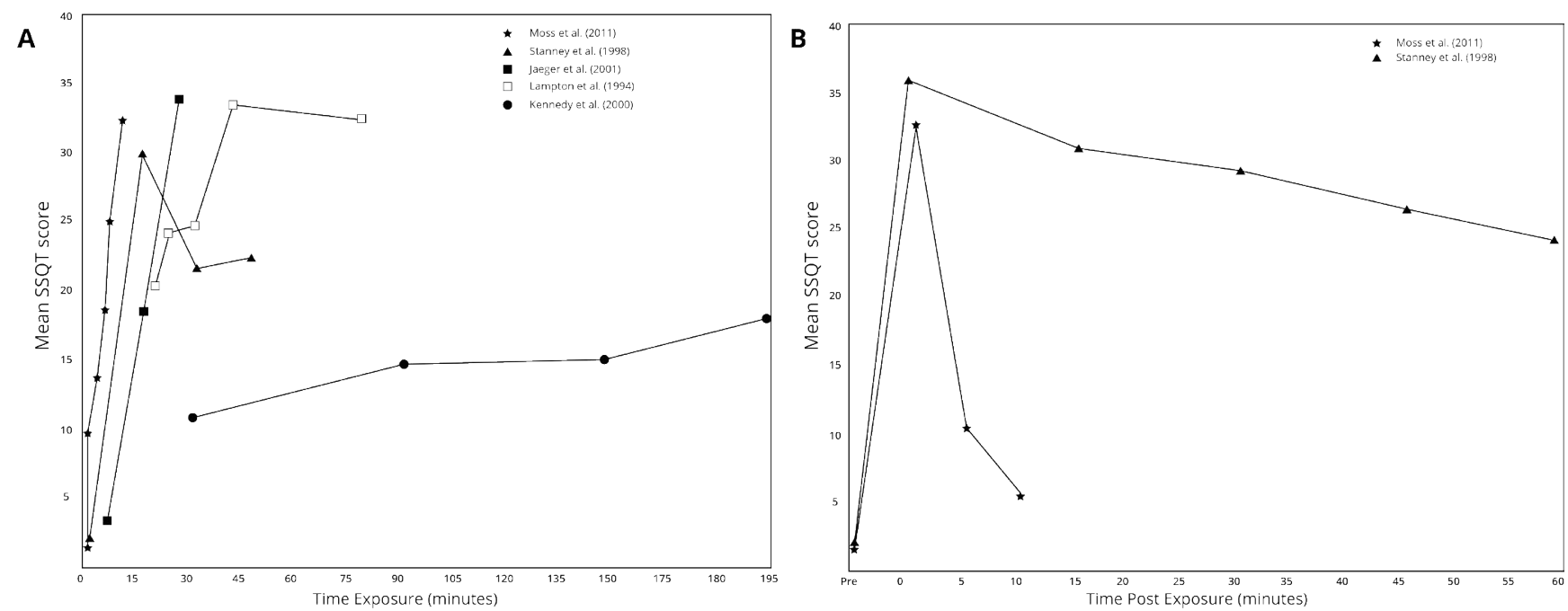

Figure 9: Mean SSQT scores by duration of exposure in different studies. A: SSQT score and exposure duration; B: SSQT score and post exposure duration. 

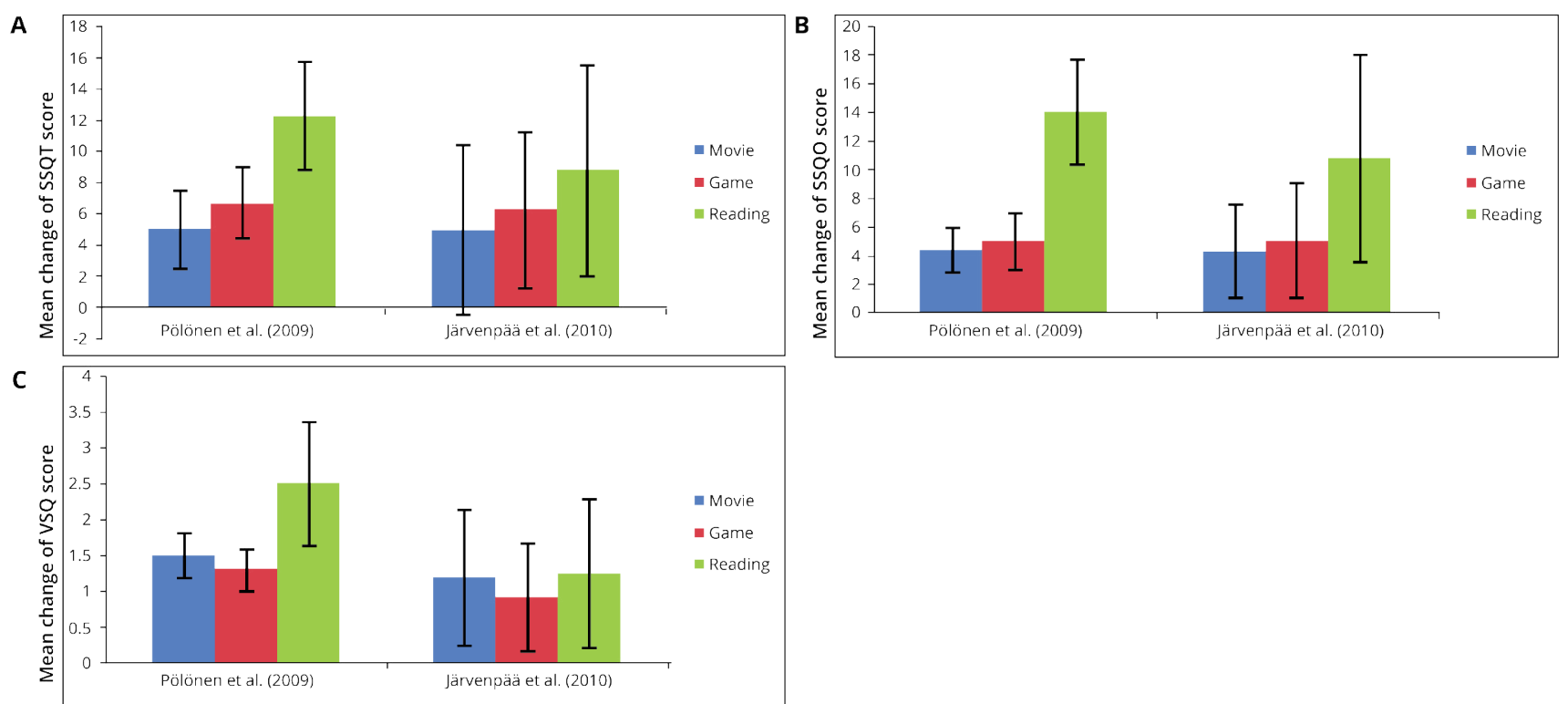

Figure 10: SSQ and VSQ Change (Post - Pre) are demonstrated after performing different tasks in two studies (higher scores = higher symptom severity). A: SSQT change; B: SSQO change; C: VSQ change. Vertical lines represent standard error of mean.

and visual strain questionnaires scores. Furthermore, HMD exposure was associated with higher scores of mean changes of SSQT and SSQO compared to other traditional displays, such as TV and desktop computer displays.

Theoretically, HMDs with sub-optimal designs were used in the earlier articles, i.e., those published before 2000. The visual discomfort reported in those papers might have been a result of their poor design, rather than valid observations. Therefore, the meta-analysis from those papers published before $\mathbf{2 0 0 0}$ may have substantially overestimated the incidence of HMD-induced visual discomfort. For example, the Virtual Research V6 HMD used for Stanney's 1998 study was a mid-range display made by the US-based Virtual Research System Inc. and had a lower brightness and poorer color presentation compared to the updated Virtual Research V8 HMD used for Sharples' 2008 study [32,54]. These advancements in the manufacturer's HMD technology may have produced a higher mean change of the questionnaire score when compared to scores from participants who had used the older Virtual Research V6.

In order to rule out any significant influence from the papers published prior to 2000, (i.e., to assess the reliability of our meta-analysis), our sensitivity analysis excluded the four studies published before 2000 . This exclusion did not change the outcome of our meta-analysis; i.e. the result after eliminating the old papers was statistically consistent with the result of original meta-analysis. Even though these questionnaires are self-reported subjective evaluation methods, they provide converging evidence that HMD-based VR causes visual discomfort. These findings are consistent with a cross-sectional survey of 953 questionnaires related to VIMS, in which almost $35 \%$ of the respondents reported tired eyes during 3D movies [98]. The results suggest a need for raising public awareness about the visual discomfort that individuals may suffer after exposure to HMDs. We recommend that the HMD industry and manufacturers address the visual discomfort issue before their products become commonly used.

To date, no controlled studies have evaluated the extent to which user subjective responses are determined by characteristics resulting from pre- and post-test measures. Young gave subjects SSQ's either pre- and post-VR immersion, or only post immersion. Participant reports of sickness after immersion in VR showed higher scores when both pre- and post-test questionnaires were given to the participants than when only a posttest questionnaire was used [23]. These results are notable because measurements of sickness by both preand post-self-report questionnaires are significantly biased due to demand characteristics, and may substantially overestimate the incidence of HMD-induced visual discomfort. We suggest that comparative studies of the visual effects of HMD-based VEs employ experimental designs that are not subject to such biases, or at least take measures to balance these biases. Alternatively, more objective measures could be used systematically in order to evaluate visual effects after HMD exposure.

\section{User Settings Risk Factors}

Our systematic review also shows that many factors impact HMD-induced VIMS. These factors include the characteristics of the device system, the participants in the studies we included, and the tasks they were asked to perform. Device system variables included viewing mode (e.g. monocular, binocular or dichoptic), headset design (e.g. fit, weight), optics (e.g. misalignment in the optics; contrast, luminance), Field Of View (FOV), and time lag (i.e. transport delay). HMD weight has been associated with the experience of visual discomfort and 
injury [99]. A key consideration for HMD design must be that weight is within the level of human tolerance to minimize head and neck fatigue. With the decrease in cost of components, HMD design has moved to more ergonomic HMD systems, which has been reflected in the adoption of mobile systems, such as Samsung Gear and Google DayDream.

Symptoms of eyestrain and blurry vision were significantly higher in monocular mode than in other modes $[18,67,72]$. The use of HMDs in stereoscopic mode is less comfortable than in non-stereoscopic mode $[14,17,69$ 71]. Spatial properties of the display, i.e., Field of View (FOV), may be implicated in producing visual discomfort symptoms [34,51]. The FOV studies show that narrow FOV ( $<50$ degrees) reduces the perception of self-motion and wide FOV ( $>100$ degrees) may increase the presence and level of simulator sickness. Patterson, et al. recommend a minimum $60^{\circ} \mathrm{FOV}$ to achieve a full sense of immersion [100].

\section{Device Risk Factors}

Resolution contributes to overall image quality but also directly affects the users' experience of VIMS. It is often uncomfortable to view low-quality images that are noisy or blurry. Anatomically, the central retinal fovea has the highest number of photoreceptors and the highest capacity for resolving an image [101]. While the limit of human visual resolution is 1 minute of arc at the central fovea, few HMDs can achieve this, primarily due to current technological limitations. The result can be a pixelated experience [101]. It is important to provide the highest possible resolution in the central field of view of the virtual environment to truly simulate a real-life experience and mimic the viewing characteristics of human vision. Some devices attempt to achieve this by creating a gradient of resolution with the highest resolution in the central field of view and the lowest resolution at the periphery $[101,102]$. The potential trade off of higher resolution is the overexposure of energy from the display, given the proximal distance of the display to the eyes.

Time lag between an individual's action and the system's reaction potentially could influence a user's experience of VIMS symptoms, as it affects human perception of visual and vestibular cues [33,51,64,65]. Therefore, reducing the sensor error of HMD systems may minimize the VIMS experience. HMD optical characteristics, such as eye relief (a fixed distance from the eyepiece lens to its exit pupil), convergence demand, horizontal disparity, vertical misalignment of displays, inter-ocular rotation difference, vertical-horizontal magnification differences, luminance, focus differences, temporal asynchrony, focal distance, field curvature difference and Inter-Pupillary Distance (IPD), are all potential factors that can induce visual discomfort and headache when they are poorly aligned or adjusted [37$39,66,68,73-75,100,103-106]$. Another consideration is the type of optics used in HMD systems, single focus lens systems vs. multifocal lens systems, with the latter lending to more natural adaptive zones for multiple focal lengths typically encountered in VR environments, especially interactive experiences.

High rates of ocular symptoms may be associated with certain device characteristics (Table 1). For example, the VIMS experienced with the Vuzix may be attributable to the focal distance of the display $(5 \mathrm{~m} / 2.4 \mathrm{~m})$, luminance level $\left(24 \mathrm{~cd} / \mathrm{m}^{2}\right)$, and vertical misalignment $\left(0.8^{\circ}\right)$. Conversely, the low ocular symptom rate in the MyVu may be explained by its luminance level $(97 \mathrm{~cd} /$ $\mathrm{m}^{2}$ ), lack of vertical misalignment $\left(0^{\circ}\right)$, physical design and assigned tasks. It is essential to note that technical advances have reduced obvious problems such as physical ergonomic issues including HMD weight, system time delay, and luminance.

It is also important to note that the conflict between visual and vestibular input remains a significant problem. In other words, the VIMS from HMD exposure is not simply a "technical problem" that will be resolved as the technology advances. The discomfort from the vestibular-visual mismatch will not resolve unless the mismatch itself resolves, which may involve a multifactorial process of synchronizing sensory inputs dependent on hardware specifications and software/content design.

\section{User Individual Risk Factors}

Individuals differ in their susceptibility to VIMS [107]. Age has been shown to have a significant relationship with HMD-related eyestrain symptoms [70]. Children 2-12 years of age have immature visual systems and binocular function that is worse than that of adults; this makes children more susceptible to both visual discomfort caused by HMDs and oculomotor side effects including reduced visual acuity, amblyopia, or strabismus $[21,31,108,109]$. Adults with limited fusional ranges experienced more visual discomfort, specifically with convergent eye movement in response to stimuli in VEs (Karpicka E, unpublished data). Therefore, age effect on HMDs needs to be further studied and taken into account in the design of future HMDs. In regard to gender, females reported more simulator sickness and more often withdrew from HMD-based VEs when compared to male participants $[16,19,33,48,49,70]$. This difference may be due to under-reporting of susceptibility on self-reports by males (so-called "macho effect") or hormonal effects [110]. Other possible explanation for this gender difference is that females generally have a wider FOV than males, which increases the likelihood of flicker perception and sickness susceptibility [111].

People with visual deficits may have an increased susceptibility to oculomotor side effects compared to those without such deficits, although this has yet to be verified experimentally. A past history of motion sickness has also been found to predict susceptibility to 
sickness in HMD-based VEs [49]. Individuals also differ in their ability to habituate or adapt to HMD-based VEs (i.e. plasticity), with some individuals adapting much more readily than others after repeated exposures to stimuli $[50,81-84,87]$.

It has been suggested that those with greater plasticity may be less susceptible to VIMS, although the time course to adapt may vary. Greater plasticity is associated with faster symptom reduction on repeated exposures rather than with reduction of initial symptoms [81-84]. Thus far, the characteristics of individuals with greater levels of plasticity have not been identified, and this will require further study.

\section{Other Risk Factors}

An individual's posture may also contribute to VIMS. The postural instability theory states that motion sickness occurs with a loss of postural control [112]. In a virtual environment setting, there is a sensory conflict between the virtual image and the real-world posture that increases the body's risk for motion sickness $[70,77-80,112]$. Postural stability relies on input from the visual, somatosensory, and vestibular systems. This input is processed and then controls two major reflexes, including the Vestibular Ocular Reflex (VOR) that maintains stability of visual objects on the retina as well as the vestibular spinal reflex that maintains body postural stability while an individual is in motion. Conflict between the visual and vestibular sensory inputs can give rise to postural instability (ataxia) as well as to VIMS [79]. Postural instability, which has been reported as a symptom of HMDs exposure, may last for several hours after exposure $[70,77-80,85,88]$. Special consideration for HMD user safety, as related to the risk of postural instability, must be kept in mind. For instance, HMD users should allow for adaptation and recovery time before engaging in potentially dangerous activities such as driving, or sports may be in order.

Task characteristics have been also identified as potentially affecting VIMS. The most important of these is the duration of exposure to VE. As shown in Figure 9, longer exposure to VE increases the incidence of VIMS. These symptoms may persist up to 60 minutes after exposure $[17,21,24-26,32,34,39,48,70,84,95,96]$. Another important factor shown to influence VIMS is vection (i.e. an illusion of self-motion; Table 5), with faster vection resulting in greater sickness symptoms $[17,77,91,93]$ Viewing HMD-based VR in a sitting position may reduce symptoms, as sitting reduces the demands on postural control $[22,53,78,113]$. More complicated tasks, such as reading, may induce total symptom severity scores and oculomotor-related symptom scores that are significantly higher than those observed with movies or games (Figure 10) $[39,52,64]$. These findings imply that more demanding tasks probably will create some degree of eyestrain. Increased reading sensitivity, when compared to watching a movie or playing a game, might be due to activation of different areas of the brain, which may make reading more complex than other tasks. Alternatively, reading can affect attention and blink rate, which may also contribute to an increase in VIMS. Moreover, inappropriate vertical gaze angle may cause increased oculomotor changes and visual discomfort $[30,97]$.

\section{Conclusion}

Our meta-analysis and systematic review confirms that visual discomfort occurs after exposure to current HMDs significantly more than after exposure to traditional displays. The visual discomfort induced by HMDs is influenced by the three categories of moderator factors, which indicates that the discomfort is multi-factorial and poly-symptomatic. It is conceivable that the visual discomfort induced by HMDs will diminish gradually as the quality of design of HMDs improves and the technology of the components increases; however, the discomfort may not resolve completely until the visual-vestibular mismatch is resolved. VIMS and visual discomfort continue to be obstacles for widespread acceptance of HMDs; this increases the importance of further research into VIMS. More research is needed to resolve visual-vestibular mismatch, and to develop objective methods of evaluating and quantifying VIMS symptoms such as visual/ocular changes (e.g. ocular movements), physiological changes (e.g. changes in heart rate, blink rate, EEG [electroencephalography]), and vestibular changes (e.g. perceived spatial velocity). More research focusing on the user experience is necessary, with recommended expansion of subjective assessment methods such as questionnaires (e.g. the SSQ and VSQ).

Furthermore, as the VR market expands from early consumer adoption, a burgeoning environment for VR-related software has developed. While the emphasis of our paper relates to the current hardware limitations of HMDs, the authors recommend future research also focus on the relationship of software implementation to simulation/VR sickness. For example, perceived motion in virtual environments is affected by how head motion or controls are mapped into the graphical representation of the virtual environment. To limit some of the effects of software-related VIMS, developers may limit movements in certain directions or provide a frame of reference. Recent advancements include the usage of eye tracking with foveal rendering to simulate real-world object focus in virtual environments [101].

We have proposed recommended guidelines below, in part for both hardware and software developers, to design accordingly to minimize VIMS. Although there are still hurdles related to creating seamless virtual environments, there is a lot of promise. Continued research and development of both hardware features and software implementation will continue to improve the VR experience.

Our meta-analysis has led us to propose a few key 
observations and recommendations. Our observations are as follows:

1. Lighter HMDs are associated with a decrease in discomfort;

2. Monocular presentations should be avoided, as they are associated with more discomfort compared to binocular and dichoptic presentations;

3. Exposure to VR in sitting position may decrease VIMS;

4. Complex visual tasks and reading may increase VIMS severity;

5. Rapid vection results in an increase in VIMS symptoms.

Our recommendations are as follows:

1. Manufacturers need to be attentive to system characteristics of the devices they develop and market;

2. Users should be advised that children, women, users with visual field defects, postural instability, or past history of motion sickness may be especially prone to VIMS;

3. Inexperienced users are especially susceptible to developing VIMS, and users are different in their adaptation to HMDs;

4. Users should be warned to not use HMDs for a long period of time, and to take frequent breaks;

5. Users should avoid driving or operating heavy machinery after exposure to VR until VIMS and postural instability resolve.

\section{Acknowledgements}

This study was supported in part by an unrestricted grant from Research to Prevent Blindness, Inc., New York, New York, USA, to the Department of Ophthalmology and Visual Sciences, University of Utah, Salt Lake City, Utah, USA.

We are grateful for the consultation support we received from: Michael Zyda, DSc, GamePipe Laboratory, Department of Computer Science, Viterbi School of Engineering, University of Southern California; Los Angeles, CA, USA; Kushagra Shrivastava, Marketing Technologist; Advisory Board, Vizzario; and Jacob Mederos, Lead Software Engineer, Vizzario, Davis, CA, USA. Susan Schulman, University of Utah School of Medicine, provided editorial and manuscript preparation assistance.

\section{Financial Disclosures}

Dr. Khaderi is an Advisory Board Member for Magic Leap Inc., an advisor for Medella Health, a consultant and speaker for Merz Pharma, and the founder and CEO of Vizzario. The other authors have declared that they have no financial disclosures.

\section{References}

1. Sutherland IE (1965) The Ultimate Display. Proceedings of IFIP Congres 506-508.
2. Sutherland IE (1968) A head-mounted three-dimensional display. American Federation of Information Processing Societies (AFIPS) Fall Joint Computer Conference Proceedings, Thompson Book Company, Washington, USA, 33: 757-764.

3. Kennedy RS, Hettinger LJ, Lilienthal MG (1990) Simulator Sickness. In: Crampton GH, Motion and Space Sickness. CRC Press, Boca Raton, USA, 317-341.

4. Kennedy RS, Drexler J, Kennedy RC (2010) Research in visually induced motion sickness. Appl Ergon 41: 494-503.

5. Ukai K, Kibe A (2003) Counterroll torsional eye movement in users of head-mounted displays. Displays 24: 59-63.

6. Bles W, Wertheim AH (2001) Appropriate use of virtual environments to minimise motion sickness. In: Werkhoven $P$, Breaux $R$, What is essential for virtual reality systems to meet military human performance goals? Soesterberg, The Netherlands.

7. Peli $E$ (1990) Visual issues in the use of a head-mounted monocular display. Opt Eng 883-892.

8. Kooi FL, Toet A (2004) Visual comfort of binocular and 3D displays. Displays 25: 99-108.

9. Ukai K, Howarth PA (2008) Visual fatigue caused by viewing stereoscopic motion images: Background, theories, and observations. Displays 29: 106-116.

10. Menozzi M (2000) Visual ergonomics of head-mounted displays. Japanese Psychological Research 42: 213-221.

11. Urvoy M, Barkowsky M, Le Callet P (2013) How visual fatigue and discomfort impact 3D-TV quality of experience: a comprehensive review of technological, psychophysical, and psychological factors. Ann Telecommun 68: 641-655.

12. Howarth PA (2011) Potential hazards of viewing 3-D stereoscopic television, cinema and computer games: a review. Ophthalmic Physiol Opt 31: 111-122.

13. Bando T, lijima A, Yano S (2012) Visual fatigue caused by stereoscopic images and the search for the requirement to prevent them: A review. Displays 33: 76-83.

14. Peli E (1998) The visual effects of head-mounted display (HMD) are not distinguishable from those of desk-top computer display. Vision Res 38: 2053-2066.

15. Mon-Williams M, Wann JP, Rushton S (1993) Binocular vision in a virtual world: visual deficits following the wearing of a head-mounted display. Ophthalmic and Physiological Optics 13: 387-391.

16. Lampton DR, Rodriguez ME, Cotton JE (2000) Simulator sickness symptoms during team training in immersive virtual environments. SAGE 44: 530-533.

17. Kuze J, Ukai K (2008) Subjective evaluation of visual fatigue caused by motion images. Displays 29: 159-166.

18. Sheedy J, Bergstrom N (2002) Performance and comfort on near-eye computer displays. Optom Vis Sci 79: 306-312.

19. Howarth PA, Costello PJ (1997) The occurrence of virtual simulation sickness symptoms when an HMD was used as a personal viewing system. Displays 18: 107-116.

20. Howarth PA (1999) Oculomotor changes within virtual environments. Appl Ergon 30: 59-67.

21. Kozulin P, Ames SL, McBrien NA (2009) Effects of a head-mounted display on the oculomotor system of children. Optom Vis Sci 86: 845-856.

22. Nichols S (1999) Physical ergonomics of virtual environment use. Appl Ergon 30: 79-90. 
23. Young SD, Adelstein BD, Ellis SR (2006) Demand characteristics of a questionnaire used to assess motion sickness in a virtual environment. Proceedings of the Institute of Electrical and Electronics Engineers (IEEE), Virtual Reality (VR) Conference, 97-102.

24. Rushton S, Mon-Williams M, Wann JP (1994) Binocular vision in a bi-ocular world: new-generation head-mounted displays avoid causing visual deficit. Displays 15: 255-260.

25. Ames SL, Wolffsohn JS, McBrien NA (2005) The development of a symptom questionnaire for assessing virtual reality viewing using a head-mounted display. Optom Vis Sci 82: 168-176.

26. Aaltonen V, Polonen M (2009) The effect of viewing duration on visual comfort with near-to-eye displays. SID 40: 812-814.

27. Edgar GK, Pope JCD, Craig IR (1993) Visual accommodation problems with head-up and helmet-mounted displays. SPIE Digital Library.

28. Schega L, Hamacher D, Erfuth S, Behrens-Baumann W, Reupsch J, et al. (2014) Differential effects of head-mounted displays on visual performance. Ergonomics 57: 1-11.

29. Costello PJ, Howarth PA (1996) The effects on the visual system of wearing a Head-Mounted Display for an hour. VISERG Report.

30. Mon-Williams M, Plooy A, Burgess-Limerick R, Wann J (1998) Gaze angle: a possible mechanism of visual stress in virtual reality headsets. Ergonomics 41: 280-285.

31. Rushton SK, Riddell PM (1999) Developing visual systems and exposure to virtual reality and stereo displays: Some concerns and speculations about the demands on accommodation and vergence. Appl Ergon 30: 69-78.

32. Stanney KM, Kennedy RS (1998) Aftereffects from virtual environment exposure: How long do they last? HFES Annual Meeting Proc 42: 1476-1480.

33. Stanney KM, Kennedy RS, Drexler JM, Harm DL (1999) Motion sickness and proprioceptive aftereffects following virtual environment exposure. Appl Ergon 30: 27-38.

34. Moss JD, Muth ER (2011) Characteristics of head-mounted displays and their effects on simulator sickness. Hum Factors 53: 308-319.

35. Biocca F (1992) Virtual reality technology: A Tutorial. J Commun 42: 23-72.

36. Lambooij MTM, IJsselsteijn WA, Fortuin MF, Heynderickx IEJ (2009) Visual discomfort and visual fatigue of stereoscopic displays: A Review. J Imaging Sci Technol 53: 1-14.

37. Polonen M, Jarvenpaa T, Hakkinen J (2010) Comparison of near-to-eye displays: Subjective experience and Comfort. J Disp Technol 6: 27-35.

38. Jarvenpaa T, Polonen M (2009) Advances in near-to-eye display optical characterization. SID International Symposium Digest of Technical Papers 40: 507-510.

39. Jarvenpaa T, Polonen M (2010) Optical characterization and ergonomical factors of near-to-eye displays. J Soc Inf Disp 18: 285-292.

40. Banks MS, Read JC, Allison RS, Watt SJ (2012) Stereoscopy and the human visual system. SMPTE Motion Imaging J 121: 24-43.

41. O'Hare L, Zhang T, Nefs HT, Hibbard PB (2013) Visual discomfort and depth-of-field. Iperception 4: 156-169.

42. Li J, Barkowsky M, Le Callet P (2014) Visual discomfort of stereoscopic 3D videos: Influence of 3D motion. Displays 35: 49-57.
43. Ling Y, Brinkman WP, Nefs HT, Qu C, Heynderickx I (2012) Effects of stereoscopic viewing on presence, anxiety and cybersickness in a virtual reality environment for public speaking. Presence 21: 254-267.

44. Takada $\mathrm{H}$, Miyao $\mathrm{M}$, Takada $\mathrm{M}$, Matsuura $\mathrm{Y}$, Yamamoto $\mathrm{T}$ (2012) Effect of a stereoscopic movie on body sway and head acceleration. Computer Technology and Application 3: 159-168.

45. Blom KJ, Arroyo Palacios J, Slater M (2014) The effects of rotating the self out of the body in the full virtual body ownership illusion. Perception 43: 275-294.

46. Lubos P, Bruder G, Steinicke F (2014) Analysis of direct selection in head-mounted display environments. 3DUI.

47. Lubos P, Bruder G, Steinicke F (2015) Influence of comfort on 3D selection task performance in immersive desktop setups. JVRB.

48. Jaeger BK, Mourant RR (2001) Comparison of simulator sickness using static and dynamic walking simulators. HFES Annual Meeting Proc 45: 1896-1900.

49. Kolasinski EM, Gilson RD (1998) Simulator sickness and related findings in a virtual environment. HFES Annual Meeting Proc 42: 1511-1515.

50. Ehrlich JA, Kolasinski EM (1998) A comparison of sickness symptoms between dropout and finishing participants in virtual environment studies. HFES Annual Meeting Proc 42: 1466-1470.

51. Draper MH, Viire ES, Furness TA, Gawron VJ (2001) Effects of image scale and system time delay on simulator sickness within head-coupled virtual environments. Hum Factors 43: 129-146.

52. Polonen M, Hakkinen J (2009) Near-to-eye display-An accessory for handheld multimedia devices: Subjective studies. J Display Technol 5: 358-367.

53. Merhi O, Faugloire E, Flanagan M, Stoffregen TA (2007) Motion sickness, console video games, and head-mounted displays. Hum Factors 49: 920-934.

54. Sharples S, Cobb S, Moody A, Wilson JR (2008) Virtual reality induced symptoms and effects (VRISE): Comparison of head mounted display (HMD), desktop and projection display systems. Displays 29: 58-69.

55. Robert SK, Norman EL, Kevin SB, Michael GL (1993) Simulator sickness questionnaire: An enhanced method for quantifying simulator sickness. Int J Aviation Psychol 3: 203-220.

56. Kennedy RS, Lane NE, Berbaum KS, Lilienthal MG (1993) Simulator sickness questionnaire: An enhanced method for quantifying simulator sickness. The International Journal of Aviation Psychology 3: 203-220.

57. Howarth PA, Istance HO (1985) The association between visual discomfort and the use of visual display units. Behaviour and Information Technology 4: 135-149.

58. Blehm C, Vishnu S, Khattak A, Mitra S, Yee RW (2005) Computer vision syndrome: A review. Surv Ophthalmol 50: 253-262.

59. International organization for standardization (1992) Ergonomic requirements for office work with visual display terminals (VDTs) -- Part 3: Visual display requirements.

60. International organization for standardization (2008) Ergonomics of human-system interaction -- Part 302: Terminology for electronic visual displays.

61. Gowrisankaran S, Sheedy JE (2015) Computer vision syndrome: A review. Work 52: 303-314. 
62. Villar J, Mackey ME, Carroli G, Donner A (2001) Meta-analyses in systematic reviews of randomized controlled trials in perinatal medicine: comparison of fixed and random effects models. Stat Med 20: 3635-3647.

63. Kennedy RS, Fowlkes JE (1992) Simulator Sickness Is Polygenic and polysymptomatic: Implications for Research. The International Journal of Aviation Psychology 2: 23-38.

64. Nelson WT, Roe MM, Bolia RS, Morley RM (2000) Assessing Simulator Sickness in a See-Through HMD: Effects of Time Delay, Time on Task, and Task Complexity. Air Force Research Laboratory, Wright-Patterson, Ohio, USA.

65. St. Pierre ME, Banerjee S, Hoover AW, Muth ER (2015) The effects of $0.2 \mathrm{~Hz}$ varying latency with $20-100$ ms varying amplitude on simulator sickness in a helmet mounted display. Displays 36: 1-8.

66. Aykent B, Zhao Y, Merienne F, Kemeny A (2014) Simulation sickness comparison between a limited field of view virtual reality head mounted display (Oculus) and a medium range field of view static ecological driving simulator (Eco2). Driving Simulation Conference Europe Proceedings 65-71.

67. Kooi FL (1997) Visual strain: a comparison of monitors and head-mounted displays. Proceedings Imaging Sciences and Display Technologies 2949.

68. Moss J, Scisco JL, Muth E (2008) Simulator Sickness during Head Mounted Display (HMD) of Real World Video Captured Scenes. Proceedings of the Human Factors and Ergonomics Society Annual Meeting 52: 1631-1634.

69. Ehrlich JA (1997) Simulator sickness and HMD configurations. Proceedings Telemanipulator and Telepresence Technologies IV 3206.

70. Häkkinen J, Vuori T, Puhakka M (2002) Postural stability and sickness symptoms after HMD use. Proceedings of the IEEE International Conference on Systems, Man and Cybernetics 1: 147-152.

71. Häkkinen J, Pölönen M, Takatalo J, Nyman G (2006) Simulator Sickness in virtual display gaming: a comparison of stereoscopic and non-stereoscopic situations. Proceedings of the 8th Conference on Human-Computer Interaction with Mobile Devices and Services 227-230.

72. Moffitt K (1989) Ocular Responses To Monocular And Binocular Helmet-Mounted Display Configurations. Proc SPIE Helmet-Mounted Displays 1116: 142.

73. Kim K, Rosenthal MZ, Zielinski DJ, Brady R (2014) Effects of virtual environment platforms on emotional responses. Comput Methods Programs Biomed 113: 882-893.

74. Pölönen M, Järvenpää T, Häkkinen J (2012) Reading e-books on a near-to-eye display: Comparison between a small-sized multimedia display and a hard copy. Displays 33: $157-167$

75. Vlad R, Nahorna O, Ladret P, Guerin A (2013) The influence of the visualization task on the simulator sickness symptoms - A comparative SSQ study on 3DTV and 3D immersive glasses. 3DTV-Conference: The True Vision-Capture, Transmission and Display of 3D Video (3DTV-CON) $1-4$.

76. Mourant RR, Thattacheny TR (2000) Simulator sickness in a virtual environments driving simulator. Proceedings of the Human Factors and Ergonomics Society Annual Meeting 534-537.

77. Smart LJ Jr, Stoffregen TA, Bardy BG (2002) Visually induced motion sickness predicted by postural instability. Hum Factors 44: 451-465.
78. Owen N, Leadbetter AG, Yardley L (1998) Relationship between postural control and motion sickness in healthy subjects. Brain Res Bull 47: 471-474.

79. Cobb SV (1999) Measurement of postural stability before and after immersion in a virtual environment. Appl Ergon 30: 47-57.

80. Stoffregen TA, Faugloire E, Yoshida K, Flanagan MB, Merhi $O$ (2008) Motion sickness and postural sway in console video games. Hum Factors 50: 322-331.

81. Regan EC (1995) Some evidence of adaptation to immersion in virtual reality. Displays 16: 135-139.

82. Hill KJ, Howarth PA (2000) Habituation to the side effects of immersion in a virtual environment. Displays 21: 25-30.

83. Howarth PA, Hodder SG (2008) Characteristics of habituation to motion in a virtual environment. Displays 29: 117-123.

84. Kennedy RS, Stanney KM, Dunlap WP (2000) Duration and Exposure to Virtual Environments: Sickness Curves During and Across Sessions. Presence: Teleoperators and Virtual Environments 9: 463-472.

85. Takada H, Matsuura Y, Takada M, Miyao M (2011) Comparison in Degree of the Motion Sickness Induced by a 3-D Movie on an LCD and an HMD. In: Shumaker R, Virtual and Mixed Reality - New Trends. Springer-Verlag Berlin, Germany, 371-379.

86. Kotulak JC, Morse SE (1995) Oculomotor responses with aviator helmet-mounted displays and their relation to inflight symptoms. Hum Factors 37: 699-710.

87. Ehrlich JA, Singer MJ, Allen RC (1998) Relationships between head-shoulder divergences and sickness in a virtual environment. Proceedings of the Human Factors and Ergonomics Society Annual Meeting 42: 1471-1475.

88. Kutsuna K, Matsuura Y, Fujikake K, Miyao M, Takada H (2013) Comparison of form in potential functions while maintaining upright posture during exposure to stereoscopic video clips. Conf Proc IEEE Eng Med Biol Soc 7200-7203.

89. Morse SE, Jiang BC (1999) Oculomotor function after virtual reality use differentiates symptomatic from asymptomatic individuals. Optom Vis Sci 76: 637-642.

90. Davis S, Nesbitt K, Nalivaiko E (2015) Comparing the onset of cybersickness using the Oculus Rift and two virtual roller coasters. In: Pisan Y, Nesbitt K, Blackmore K, Proceedings of the 11th Australasian Conference on Interactive Entertainment (IE 2015). Conferences in Research and Practice in Information Technology (CRPIT) 167: 3-14.

91. Jang DP, Kim IY, Nam SW, Wiederhold BK, Wiederhold MD, et al. (2002) Analysis of physiological response to two virtual environments: driving and flying simulation. Cyberpsychol Behav 5: 11-18.

92. So RH, Lo WT, Ho AT (2001) Effects of navigation speed on motion sickness caused by an immersive virtual environment. Hum Factors 43: 452-461.

93. So RHY, Lo WT (1998) Cybersickness with Virtual Reality Training Applications: a claustrophobia phenomenon with head mounted displays? First World Congress on Ergonomics for Global Quality and Productivity 209-212.

94. Lo WT, So RH (2001) Cybersickness in the presence of scene rotational movements along different axes. Appl Ergon 32: 1-14.

95. Lampton DR, Kolasinski EM, Knerr BW, Bliss JP, Bailey $\mathrm{JH}$, et al. (1994) Side effects and after effects of immersion in virtual environments. Proceedings of the Human Factors and Ergonomics Society Annual Meeting 38: 1154-1157. 
96. Steinicke F, Bruder G (2014) A Self-Experimentation Report about Long-Term Use of Fully-Immersive Technology. Proceedings of the $2^{\text {nd }}$ ACM symposium on Spatial user interaction 66-69.

97. Pölönen M, Aaltonen V, Nyman G, Häkkinen J (2008) Influence of the monocular near-to-eye display position on the visual system during dual-task performance. Journal of the Society for Information Display 16: 1083-1087.

98. Solimini AG, Mannocci A, Di Thiene D, La Torre G (2012) A survey of visually induced symptoms and associated factors in spectators of three dimensional stereoscopic movies. BMC Public Health 12: 779.

99. Di Zio P, Lackner JR (1992) Spatial orientation, adaptation and motion sickness in real and virtual environments. Presence: Teleoperators and Virtual Environments 1: 319-328.

100. Patterson R, Winterbottom MD, Pierce BJ (2006) Perceptual issues in the use of head-mounted visual displays. Hum Factors 48: 555-573.

101. Fergason JL (1998) Optical system for a head mounted display combining high and low-resolution images.

102. National Research Council (1995) Virtual reality: scientific and technological challenges. National Academies Press, Washington.

103. Melzer JE, Brozoski FT, Letowski TR, Harding TH, Rash CE (2009) Guidelines for HMD design. In: Rash CE, Helmet-Mounted Displays: Sensation, Perception and Cognition Issues. Army Aeromedical Research Laboratory Fort Rucker, USA, 805-848.

104. Moffitt K (2011) Designing HMDs for viewing comfort. In: Melzer JE, Moffitt K, Head-Mounted Displays: Designing for the User. North Charleston, USA, 117-145.
105. Cakmakci O, Rolland J (2006) Head-Worn Displays: A Review. Journal of Display Technology 2: 199-216.

106. Task HL (2011) HMD image source, optics, and the visual interface. In: Melzer JE, Moffitt K, Head-Mounted Displays: Designing for the User. North Charleston, USA, 55-82.

107. Turner M, Love S (2003) Individual differences in user experience of head mounted displays: personality and visuo-spatial attention effects. In: de Waard D, Brookhuis KA, Sommer SM, Verwey WB, Human Factors in the Age of Virtual Reality. Shaker Publishing, Maastricht, Netherlands 31-42.

108. Ciuffreda KJ, Levi DM, Selenow A (1991) Amblyopia: Basic and Clinical Aspects. Butterworth-Heinemann, Boston, USA.

109. Reason JT, Brand JJ (1975) Motion Sickness. Academic Press, London, England.

110. Kennedy RS, Lanham SD, Massey CJ, Drexler JM (1995) Gender differences in simulator sickness incidence: implications for military virtual reality systems. Safe Journal 25: 69-76.

111. La Viola JJ Jr (2000) A Discussion of Cybersickness in Virtual Environments. SIGCHI Bulletin 32: 47-56.

112. Smart LJ Jr, Stoffregen TA, Bardy BG (2002) Visually induced motion sickness predicted by postural instability. Human Factors 44: 451-465.

113. Regan EC, Price KR (1993) Some side-effects of immersion virtual reality: The effects of increasing head movements, of rapid interaction, and of seating subjects. Army Personnel Research Establishment, Farnborough, UK. 